\title{
Molecular Determinants for Modulation of Persistent Sodium Current by G-Protein $\beta \gamma$ Subunits
}

\author{
Massimo Mantegazza, ${ }^{1,2 \star}$ Frank H. Yu, ${ }^{1 *}$ Andrew J. Powell, ${ }^{3}$ Jeffrey J. Clare, ${ }^{3}$ William A. Catterall, ${ }^{1}$ and Todd Scheuer ${ }^{1}$ \\ ${ }^{1}$ Department of Pharmacology, University of Washington School of Medicine, Seattle, Washington 98195-7280, ${ }^{2}$ Department of Neurophysiology, Istituto \\ Neurologico Besta, 20126 Milan, Italy, and 3 Department of Gene Expression and Protein Biochemistry, GlaxoSmithKline, Stevenage, Herts SG1 2NY, United \\ Kingdom
}

\begin{abstract}
Voltage-gated sodium channels are responsible for the upstroke of the action potential in most excitable cells, and their fast inactivation is essential for controlling electrical signaling. In addition, a noninactivating, persistent component of sodium current, $I_{\mathrm{NaP}}$, has been implicated in integrative functions of neurons including threshold for firing, neuronal bursting, and signal integration. G-protein $\beta \gamma$ subunits increase $I_{\mathrm{NaP}}$, but the sodium channel subtypes that conduct $I_{\mathrm{NaP}}$ and the target site(s) on the sodium channel molecule required for modulation by G $\beta \gamma$ are poorly defined. Here, we show that $I_{\mathrm{NaP}}$ conducted by $\mathrm{Na}_{\mathrm{v}} 1.1$ and $\mathrm{Na}_{\mathrm{v}} 1.2$ channels $\left(\mathrm{Na}_{\mathrm{v}} 1.1>\mathrm{Na}_{\mathrm{v}} 1.2\right)$ is modulated by $\mathrm{G} \beta \gamma ; \mathrm{Na}_{\mathrm{v}} 1.4$ and $\mathrm{Na}_{\mathrm{v}} 1.5$ channels produce smaller $I_{\mathrm{NaP}}$ that is not regulated by $\mathrm{G} \beta \gamma$. These qualitative differences in modulation by $\mathrm{G} \beta \gamma$ are determined by the transmembrane body of the sodium channels rather than their cytoplasmic $\mathrm{C}$-terminal domains, which have been implicated previously in modulation by $\mathrm{G} \beta \gamma$. However, the $\mathrm{C}$-terminal domains determine the quantitative extent of modulation of $\mathrm{Na}_{\mathrm{v}} 1.2$ channels by $\mathrm{G} \beta \gamma$. Studies of chimeric and truncated $\mathrm{Na}_{\mathrm{v}} 1.2$ channels identify molecular determinants that affect modulation of $I_{\mathrm{NaP}}$ located between amino acid residue 1890 and the $\mathrm{C}$ terminus at residue 2005. The last 28 amino acid residues of the $\mathrm{C}$ terminus are sufficient to support modulation by $\mathrm{G} \beta \gamma$ when attached to the proximal $\mathrm{C}$-terminal domain. Our results further define the sodium channel subtypes that generate $I_{\mathrm{NaP}}$ and identify crucial molecular determinants in the C-terminal domain required for modulation by $\mathrm{G} \beta \gamma$ when attached to the transmembrane body of a responsive sodium channel.
\end{abstract}

Key words: sodium; channels; G-proteins; inactivation; neuromodulation; excitability

\section{Introduction}

Voltage-gated $\mathrm{Na}^{+}$channels are essential for neuronal excitability. They initiate fast action potentials and shape subthreshold electrical properties that contribute to important integrative functions. Voltage-gated $\mathrm{Na}^{+}$channels are complexes of a poreforming $\alpha$ subunit and auxiliary $\beta$ subunits (Catterall, 2000). The primary sequence of the $\alpha$ subunit contains four homologous domains (I-IV), each containing six predicted transmembrane $\alpha$-helices (S1-S6). Five different $\alpha$ subunits are expressed in adult brain: $\mathrm{Na}_{\mathrm{v}} 1.1, \mathrm{Na}_{\mathrm{v}} 1.2, \mathrm{Na}_{\mathrm{v}} 1.3, \mathrm{Na}_{\mathrm{v}} 1.5$, and $\mathrm{Na}_{\mathrm{v}} 1.6$ (Goldin et al., 2000).

In addition to the transient rapidly inactivating sodium current $\left(I_{\mathrm{NaT}}\right)$ (Hodgkin and Huxley, 1952), voltage-gated $\mathrm{Na}^{+}$ channels also generate a "persistent" current $\left(I_{\mathrm{NaP}}\right)$, which is maintained during long depolarizations, and whose importance in neurons has become increasingly apparent (Crill, 1996). $I_{\mathrm{NaP}}$ has been observed in multiple neuron types. It contributes to

Received Aug. 16, 2004; revised; accepted Jan. 27, 2005.

This work was supported by National Institutes of Health (NIH) Research Grant NS34801 to T.S., a Human Frontiers Science Program Fellowship to M.M., a grant from the Fondazione Pierfranco e Luisa Mariani to M.M., and NIH Research Grant NS25704 to W.A.C. We thank Dr. Mel Simon for the kind gift of plasmids encoding G-protein subunits. ${ }^{*}$ M.M. and F.H.Y. contributed equally to this work.

Correspondence should be addressed to Dr. Todd Scheuer, Department of Pharmacology, Mailstop 357280, University of Washington School of Medicine, Seattle, WA 98195-7280. E-mail: scheuer@u.washington.edu. D01:10.1523/JNEUROSCI.0104-05.2005

Copyright $\odot 2005$ Society for Neuroscience $\quad$ 0270-6474/05/253341-09\$15.00/0 shaping repetitive firing (Azouz et al., 1997; Mantegazza et al., 1998; Parri and Crunelli, 1998; Brumberg et al., 2000), generating rhythmicity (Alonso and Llinas, 1989; Pennartz et al., 1997; Pape et al., 1998; Taddese and Bean, 2002) and amplifying both IPSPs and EPSPs (Schwindt and Crill, 1995; Stuart and Sakmann, 1995; Stuart, 1999). $I_{\mathrm{NaP}}$ has also been implicated in the generation of epileptiform activities (Kearney et al., 2001), suggesting that its regulation plays a crucial role in controlling electrical excitability (Schwindt and Crill, 1995; Stuart and Sakmann, 1995; Segal and Douglas, 1997; Stuart, 1999).

Central neuronal $I_{\mathrm{NaP}}$ is subject to modulation by intracellular signal transduction pathways. It is decreased in parallel with $I_{\mathrm{NaT}}$ by activation of muscarinic acetylcholine receptors and consequent phosphorylation by protein kinase $\mathrm{C}$ in hippocampal neurons (Cantrell et al., 1996). It is increased by hypoxia and nitric oxide in hippocampal neurons (Hammarstrom and Gage, 1998, $1999,2000)$. In addition, $I_{\mathrm{NaP}}$ is increased when G-protein $\beta \gamma$ subunits are coexpressed with $\mathrm{Na}_{\mathrm{v}} 1.2$ channels (Ma et al., 1997). This increase was prevented by a putative $G \beta \gamma$-binding peptide from the $\mathrm{C}$ terminus of the $\mathrm{Na}_{\mathrm{v}} 1.2$ channel, suggesting that G-protein $\beta \gamma$ subunits interact with that C-terminal site during modulation (Ma et al., 1997). Consistent with this idea, G-protein $\beta$ subunits immunoprecipitate with sodium channel $\alpha$ subunits from cortical neuron preparations (Marin et al., 2001).

In the experiments presented here, we have compared modulation of $I_{\mathrm{NaP}}$ by G-protein $\beta \gamma$ subunits for $\mathrm{Na}_{\mathrm{v}} 1.1, \mathrm{Na}_{\mathrm{v}} 1.2$, 
$\mathrm{Na}_{\mathrm{v}} 1.4$, and $\mathrm{Na}_{\mathrm{v}} 1.5$ channels. We show that both $\mathrm{Na}_{\mathrm{v}} 1.1$ and $\mathrm{Na}_{\mathrm{v}} 1.2$ conduct $I_{\mathrm{NaP}}\left(\mathrm{Na}_{\mathrm{v}} 1.1>\mathrm{Na}_{\mathrm{v}} 1.2\right)$ that can be modulated by $\mathrm{G} \beta \gamma$, but $\mathrm{Na}_{\mathrm{v}} 1.4$ and $\mathrm{Na}_{\mathrm{v}} 1.5$ do not. Analysis of channel chimeras reveals that the transmembrane bodies of $\mathrm{Na}_{\mathrm{v}} 1.4$ and $\mathrm{Na}_{\mathrm{v}} 1.5$ channels are responsible for their lack of G-protein modulation rather than their $\mathrm{C}$-terminal domains. However, the quantitative extent of modulation of $\mathrm{Na}_{\mathrm{v}} 1.2$ channels is critically dependent on the C-terminal domain. Through analysis of deletion mutants, we identify new molecular determinants for modulation in the $\mathrm{Na}_{\mathrm{v}} 1.2$ channels in the $\mathrm{C}$ terminus and show that the final 28 amino acids are necessary for generation of $I_{\mathrm{NaP}}$ and can substitute for the entire distal half of the $\mathrm{C}$ terminus in supporting regulation by $\mathrm{G} \beta \gamma$.

\section{Materials and Methods}

Isolation of cDNA for $h \mathrm{Na}_{v} 1.1$ and generation of cell lines CL1 and CL2. Six overlapping clones spanning the human $\mathrm{Na}_{\mathrm{v}} 1.1$ coding region were isolated from human cerebellum and medulla cDNA libraries. A full-length cDNA was assembled from these partial clones using natively occurring restriction sites (BamHI, nucleotide 561; BamHI, nucleotide 2433; SphI, nucleotide 2694; NdeI, nucleotide 3786; SapI, nucleotide 5630). This was then inserted upstream of the internal ribosome entry site (IRES) element in the mammalian expression vector pCIN5 (Rees et al., 1996). Cell lines stably expressing $\mathrm{hNa}_{\mathrm{v}} 1.1$ were isolated after transfection of human embryonic kidney (HEK) 293 cells with $2 \mu \mathrm{g}$ of pCIN5-hNa 1.1 and selection for 3-4 weeks in $800 \mu \mathrm{g} / \mathrm{ml}$ Geneticin-G418 (Burbidge et al., 2002). Clonal cell lines CL1 and CL2 were isolated after two rounds of single-cell dilution cloning.

Construction of $\mathrm{Na}_{v} 1.2$ and $\mathrm{Na}_{v} 1.5$ channel mutants. The mammalian expression plasmids, $\mathrm{pCDM} 8-\mathrm{rH} 1$ encoding the rat cardiac $\mathrm{rNa}_{\mathrm{v}} 1.5 \alpha$ subunit and pCDM8-rIIA encoding the rat brain $\mathrm{rNa}_{\mathrm{v}} 1.2 \mathrm{a} \alpha$ subunit, were described previously (Qu et al., 1994; Linford et al., 1998). cDNA encoding the full-length human brain type $\mathrm{INa}^{+}$channel $\mathrm{hNa}_{\mathrm{v}} 1.1$ was in pCIN5-hNa 1.1 (Clare et al., 2000). cDNA encoding the rat skeletal muscle $\mathrm{Na}^{+}$channel $\mathrm{rNa}_{\mathrm{v}} 1.4$ (Trimmer et al., 1989) (kind gift from Dr. P. Ruben, Utah State University, Logan, UT) was subcloned into pCDM8. The chimeric $\mathrm{Na}^{+}$channel $\mathrm{rNa}_{\mathrm{v}} 1.2 / \mathrm{Na}_{\mathrm{v}} 1.5 \mathrm{C}$ terminus (CT) was described previously (Mantegazza et al., 2001). Chimeric $\mathrm{Na}^{+}$channel $\mathrm{Na}_{\mathrm{v}} 1.2 / 1.4$ CT was comprised of the $\mathrm{Na}_{\mathrm{v}} 1.4$ C-terminal cytoplasmic domain (beginning at amino acid position E1592) appended to $\mathrm{Na}_{\mathrm{v}} 1.2 \mathrm{a}$ cDNA after residue L1776. In mutant $\mathrm{Na}_{\mathrm{v}} 1.2 / 1.4$ QxxER, the $\mathrm{Na}_{\mathrm{v}} 1.2 \mathrm{a}$ sequence was changed from RIQMEER (R1876 to R1882) to KQTMEEK, the equivalent sequence in rat $\mathrm{Na}_{\mathrm{v}} 1.4$. In $\mathrm{Na}_{\mathrm{v}} 1.2 /$ AAMEAA mutant, the $\mathrm{rNa}_{\mathrm{v}} 1.2 \mathrm{a}$ sequence IQMEER beginning at I1875 was converted to AAMEAA. The truncation mutants $\mathrm{Na}_{\mathrm{v}} 1.2 \Delta \mathrm{K} 1890, \mathrm{Na}_{\mathrm{v}} 1.2 \Delta \mathrm{A} 1909$, $\mathrm{Na}_{\mathrm{v}} 1.2 \Delta \mathrm{S} 1929, \mathrm{Na}_{\mathrm{v}} 1.2 \Delta \mathrm{T} 1951, \mathrm{Na}_{\mathrm{v}} 1.2 \Delta \mathrm{S} 1977$, and $\mathrm{Na}_{\mathrm{v}} 1.2 \Delta \mathrm{K} 1998$, which delete segments of C-terminal cytoplasmic region of rat $\mathrm{Na}_{\mathrm{v}} 1.2 \mathrm{a}$, have been described previously (Mantegazza et al., 2001). The $\mathrm{Na}_{\mathrm{v}} 1.2 \mathrm{a}$ deletion mutant $\mathrm{Na}_{\mathrm{v}} 1.2 / \Delta 1891-1977$ removed an internal segment bounded by amino acid residues V1891 and S1977. Full-length cDNA of bovine G-protein $\beta_{2}$ subunit was cloned into a bicistronic mammalian expression plasmid, pIRES-enhanced yellow fluorescent protein (YFP) (Clontech, Palo Alto, CA), which encodes the yellow variant of the green fluorescent protein (GFP). This construct was called $\mathrm{pG} \beta_{2}$ IRES-YFP. The G-protein $\gamma_{3}$ subunit was cloned into a cyan variant of the same bicistronic vector and was named $\mathrm{pG} \gamma_{3}$ IRES-cyan fluorescent protein (CFP). All Na ${ }^{+}$channel mutations generated by PCR mutagenesis were sequenced in between the restriction sites used for subcloning to verify that they were free of unintended alteration of sequences.

Expression of sodium channels. The fluorescent proteins in the bicistronic vectors or the CD8 receptor in pCD8-neomycin were used as markers of transfected cells (Margolskee et al., 1993). Plasmids were cotransfected into tsA-201 cells by $\mathrm{CaPO}_{4}$ precipitation. Cells were grown to $75 \%$ confluence in $35 \mathrm{~mm}$ tissue culture dishes (Corning, Acton, MA). After addition of DNA, they were incubated at $37^{\circ} \mathrm{C}$ in $3 \%$ $\mathrm{CO}_{2}$. Twelve hours after transfection, cells were removed from the dishes using 2 mм EDTA in PBS and replated at low density for electrophysio-

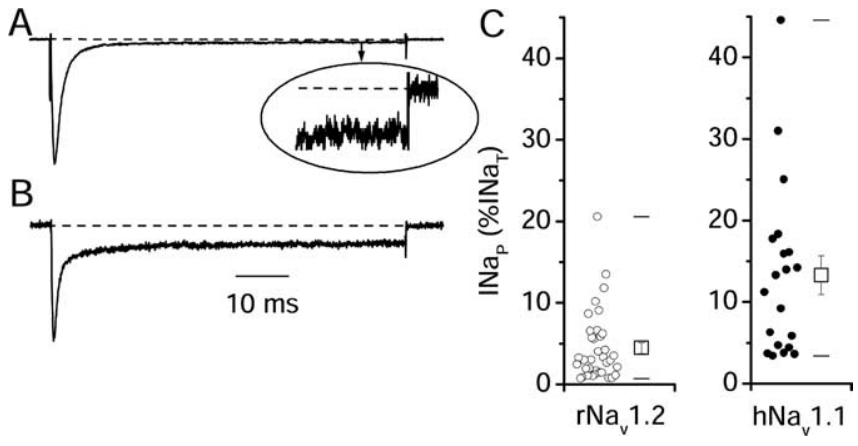

Figure 1. Normalized current traces elicited by a step stimulus to $0 \mathrm{mV}$ from a holding potential of $-70 \mathrm{mV}$ from representative tsA-201 cells transfected with $\mathrm{rNa}_{\mathrm{v}} 1.2 \mathrm{a}(\boldsymbol{A})$ or with $\mathrm{hNa}_{\mathrm{v}} 1.1(\boldsymbol{B})$. The inset in $\boldsymbol{A}$ (oval) shows the end of the pulse on a 15 -fold expanded vertical axis. $\boldsymbol{C}$, Individual data points (circles) and mean values \pm SEM (open squares) of $/ \mathrm{NaP}_{\mathrm{P}}$ as a percentage of $I_{\mathrm{NaT}}$ in tsA-201 cells transiently transfected with rNa $1.2 \mathrm{a}(n=36)$ or hNa $1.1(n=20 ; p<$ 0.01). The horizontal lines represent the first and 99 th percentiles of the range.

logical recordings. HEK293 cell lines that expressed $\mathrm{hNa}$ v1.1, CL1 and CL2, were transfected using TransFast (Promega, Madison, WI). Positive transfectants were selected visually either by anti-CD8-coated beads (Dynal, Brown Deer, WI) or by their fluorescence using a Nikon (Tokyo, Japan) Eclipse TE300 microscope for epifluorescence. Cells transfected with plasmids encoding green fluorescent proteins were selected visually using excitation/emission cubes for YFP (Chroma 41028; Chroma Technology, Rockingham, VT) and CFP (Chroma 31044v2). The tsA-201 subclone of HEK293 cells and stably transfected HEK cell lines were maintained as described previously (Herlitze et al., 1996).

Electrophysiology and data analysis. Whole-cell patch-clamp recordings were performed at room temperature using an Axopatch 200B amplifier (Axon Instruments, Union City, CA). Capacitative currents were minimized by means of the amplifier circuitry. Seventy percent prediction and $90-95 \%$ series resistance compensation were used routinely. The remaining capacity transients and leakage currents were eliminated using $\mathrm{P} / 4$ subtraction. The intracellular solution contained the following (in mM): 120 Cs-aspartate, $5 \mathrm{NaCl}, 2 \mathrm{MgCl}_{2}, 10$ EGTA, 10 HEPES, pH 7.3 with $\mathrm{CsOH}$. The extracellular solution contained the following (in $\mathrm{mm}$ ): $140 \mathrm{NaCl}, 2 \mathrm{CaCl}_{2}, 2 \mathrm{MgCl}_{2}, 10$ HEPES, pH 7.4 with $\mathrm{NaOH}$. pClamp 6.0.4 software and a Digidata 1200 interface (Axon Instruments) were used to generate the voltage stimuli and to acquire the current signals, which were filtered at 5 or $10 \mathrm{kHz}$. The data were analyzed using pClamp and Origin 6.0 (OriginLab, Northampton, MA) on a Pentium II-based personal computer (Intel, Santa Clara, CA). Unless indicated, the holding potential for voltage clamp recordings was $-70 \mathrm{mV}$.

Conductance-voltage $(G-V)$ relationships were calculated from the current-voltage $(I-V)$ relationships according to extended Ohm's law $G_{\mathrm{Na}}=I_{\mathrm{Na}} /\left(V-E_{\mathrm{Na}}\right)$, where $I_{\mathrm{Na}}$ was the peak $\mathrm{Na}^{+}$current measured at potential $V, G_{\mathrm{Na}}$ was the sodium conductance, and $E_{\mathrm{Na}}$ was the calculated Nernst equilibrium potential for $\mathrm{Na}^{+}$. Curves were fit using the Levenberg-Marquardt algorithm. The voltage dependence of activation and voltage dependence of fast inactivation were fitted to Boltzmann relationships of the following form: normalized $G_{\mathrm{Na}}=((1-C) /(1+\exp$ $\left.\left.\left(V-V_{1 / 2}\right) / k\right)\right)+C$, where $V$ was the membrane potential, $V_{1 / 2}$ was the voltage of half-maximal activation or inactivation, $k$ was a slope factor, and $C$ was the baseline noninactivating current. For cells with large $I_{\mathrm{NaP}}$, a second Boltzmann component was included, as follows: $((1-C-$ $\left.A 2) /\left(1+\exp \left(\left(V-V_{1 / 2,1}\right) / k_{1}\right)\right)\right)+\left(A 2 /\left(1+\exp \left(\left(V-V_{1 / 2,2}\right) / k_{2}\right)\right)\right)+C$. The statistical results are given as mean \pm SEM. The threshold $p$ value for statistical significance was 0.05 .

Sequence alignments were produced by ClustalW (Thompson et al., 1994) followed by manual editing to produce the alignments shown.

\section{Results}

$I_{\mathrm{NaP}}$ conducted by $\mathrm{rNa}_{\mathrm{v}} 1.2 \mathrm{a}$ and $\mathrm{hNa} \mathrm{v}_{\mathrm{v}} 1.1$ channels

Sodium currents produced by expression of $\mathrm{Na}_{\mathrm{v}} 1.2$ channels in tsA-201 cells have two components: a large, rapidly inactivating 
A

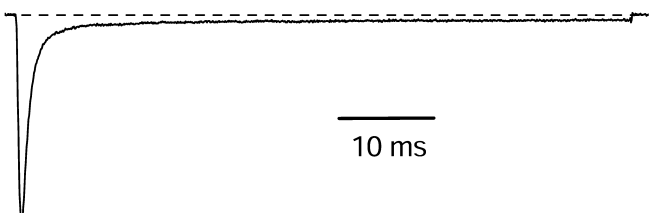

B
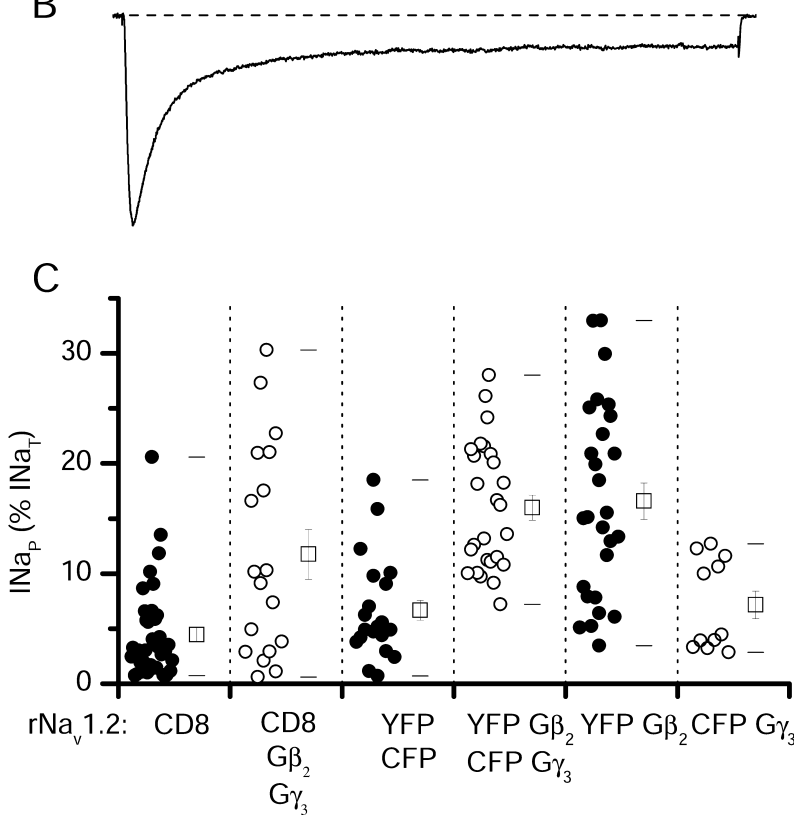

Figure 2. Changes in $I_{\text {NaP }}$ produced by $\mathrm{Na}_{\mathrm{v}} 1.2$ induced by cotransfection of $\mathrm{G}$-protein $\beta$ and $\gamma$ subunits. $A, B$, Current traces from representative tsA-201 cells transfected with $\mathrm{rNa}_{\mathrm{v}} 1.2 \mathrm{a}$ alone $(\boldsymbol{A})$ or cotransfected with $\mathrm{G} \beta_{2}$ and $\mathrm{G} \gamma_{3}(\boldsymbol{B})$ elicited by a depolarization to $0 \mathrm{mV}$ from a holding potential of $-70 \mathrm{mV}$. C, Individual data points (circles) and mean values \pm SEM (open squares) of $I_{\text {NaP }}$ as a percentage of $I_{\text {NaT }}$ in tsA-201 cells transfected with $r^{N a} a_{v} 1.2 a$ and the indicated plasmids. The whiskers represent the first and 99th percentile values. Mean values were the following, for cells transfected with (from left to right): CD8 receptor as reporter gene $\left(I_{\mathrm{NaP}}=4.5 \pm 0.7 \% ; n=36\right) ; \mathrm{rNa}_{\mathrm{v}} 1.2 \mathrm{a}, \mathrm{G} \beta_{2}, \mathrm{G} \gamma_{3}$, and $\mathrm{CD} 8$ receptor $\left(I_{\mathrm{NaP}}=11.8 \pm 2.3 \% ; n=\right.$ 18); $r \mathrm{Na}_{\mathrm{v}} 1$.2a with YFP and (FP as reporter genes $\left(I_{\mathrm{NaP}}=6.8 \pm 1.0 \% ; n=20\right) ; \mathrm{rNa} \mathrm{v}_{\mathrm{v}} 1.2 \mathrm{a}, \mathrm{G} \beta_{2}$ expressed in a bicistronic vector with YFP and $G \gamma_{3}$ expressed in a bicistronic vector with CFP $\left(I_{\mathrm{NaP}}=16 \pm 1.0 \% ; n=26\right) ; \mathrm{rNa} \mathrm{v}_{\mathrm{v}} 1.2 \mathrm{a}$ and $\mathrm{G} \beta_{2}$ expressed in a bicistronic vector with YFP $\left(I_{\mathrm{NaP}}=17 \pm 2 \% ; n=27\right) ; \mathrm{rNa} \mathrm{v}_{\mathrm{v}}$.2a and $\mathrm{G} \gamma_{3}$ expressed in a bicistronic vector together with YFP $\left(I_{\text {NaP }}=7 \pm 1 \% ; n=11\right)$. Because the CD8 control group and the CFP YFP control group did not differ significantly, they were pooled for additional statistical comparisons (mean of pooled data, $\left.I_{\mathrm{NaP}}=5.3 \pm 0.6 \% ; n=56\right)$.

A

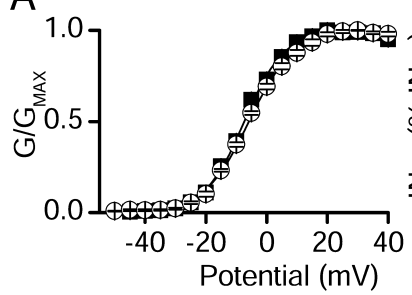

$\mathrm{B}$

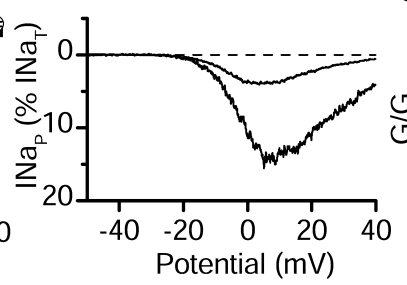

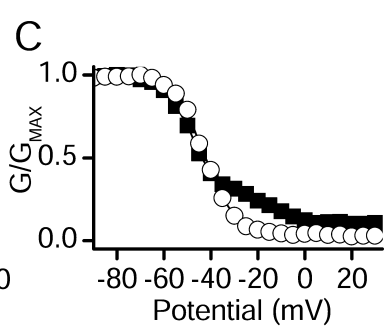

Figure 3. Properties of $I_{\mathrm{NaT}}$ and $I_{\mathrm{NaP}}$ in tsA-201 cells transfected with $\mathrm{Na}_{\mathrm{v}} 1.2$ alone or cotransfected with $\mathrm{G} \beta_{2} \gamma_{3}$. $A$, Mean voltage dependence of activation for cells transfected with $\mathrm{rNa}_{\mathrm{v}} 1.2 \mathrm{a}$ alone (open circles) and cells cotransfected with $r \mathrm{Na}_{\mathrm{v}} 1.2 \mathrm{a}$ and $\mathrm{G} \beta_{2} \gamma_{3}$ (filled squares). The solid lines are the Boltzmann fits that gave the following parameters (see Materials and Methods for definitions): $\mathrm{Na}_{\mathrm{v}} 1.2$ alone, $n=9, V_{1 / 2}=-5.9 \pm 0.2 \mathrm{mV}, k=-7.3 \pm 0.2 \mathrm{mV} ; \mathrm{Na}_{\mathrm{v}} 1.2$ a plus G $\beta_{2} \gamma_{3}, n=13, V_{1 / 2}=-7.2 \pm$

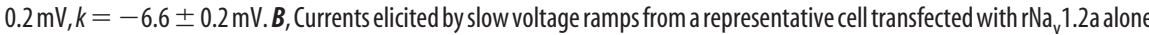
(smaller current) or cotransfected with $\mathrm{G} \beta_{2} \gamma_{3}$ (larger current). $\boldsymbol{C}$, Voltage dependence of inactivation from representative cells with the mean level of $I_{\mathrm{NaP}}$ determined with $100 \mathrm{~ms}$ prepulses to a variable voltage followed by a test depolarization to $0 \mathrm{mV}$ for $\mathrm{Na}_{v}$ 1.2a alone (open circles) or cotransfected with $\mathrm{G} \beta_{2} \gamma_{3}$ (filled squares). Normalized test pulse current is plotted as a function of prepulse potential. Mean parameters derived from fits of Boltzmann functions to the data were: $\mathrm{rNa}_{\mathrm{v}} 1.2 \mathrm{a}$ alone, $n=7, V_{1 / 2}=$ $-44.1 \pm 0.2, k=7.3 \pm 0.1, C=0.023 \pm 0.002 ; r^{2 N a} 1.2$ a plus $\mathrm{G}_{2} \gamma_{3}, n=13$ (fit with the sum of 2 Boltzmann components), $\left.V_{1 / 2,1}=-45.1 \pm 0.4, k_{1}=8.3 \pm 0.4, A 2=0.35, V_{1 / 2,2}=-10.0 \pm 0.7, k_{2}=6.0 \pm 0.7, C=0.117 \pm 0.003\right)$. component followed by a persistent component that fails to inactivate by the end of $60 \mathrm{~ms}$ depolarizations (Fig. $1 A$ ). $I_{\mathrm{NaP}}$ was quantitated as the mean current remaining between 45 and $55 \mathrm{~ms}$ after the beginning of the voltage step and expressed as a percentage of $I_{\mathrm{NaT}}$. The level of $I_{\mathrm{NaP}}$ varied considerably from cell to cell with a mean of $4.5 \pm 0.7 \%$ of $I_{\mathrm{NaT}}\left(n=36\right.$ ) (Fig. $1 C$ ). $\mathrm{hNa}_{\mathrm{v}} 1.1$ cons conducted signifi$20 ; p<0.01$ ) (Fig. $1 B, C$ ), similar to the results of Smith and Goldin (1998) for expression of $\mathrm{rNa}_{\mathrm{v}} 1.1$ in Xenopus oocytes. The variability of the fraction of $I_{\mathrm{NaP}}$ versus $\mathrm{I}_{\mathrm{NaT}}$ among single clonal tsA-201 cells transfected with identical cDNA for either $\mathrm{rNa}_{\mathrm{v}} 1.2 \mathrm{a}$ and $\mathrm{hNa}_{\mathrm{v}} 1.1$ channels (Fig. 1C) suggests that cellular level of $I_{\mathrm{NaP}}$.

\section{Modulation of $I_{\mathrm{NaP}}$ through $\mathrm{rNa}_{\mathrm{v}} 1.2 \mathrm{a}$ channels by $\mathrm{G} \boldsymbol{\beta} \boldsymbol{\gamma}$}

$I_{\mathrm{NaP}}$ conducted by $\mathrm{Na}_{\mathrm{v}} 1.2$ channels is increased by coexpression of G-protein $\beta \gamma$ subunits (Fig. 2 B,C) (Ma et al., 1997). Transfection of $\mathrm{G} \beta_{2} \gamma_{3}$ increased $I_{\mathrm{NaP}}$ from $4.5 \pm 0.7$ to $11.8 \pm 2.3 \%(n=$ 18) (Fig. 2C). The level of $I_{\mathrm{NaP}}$ obtained with cotransfection of plasmids encoding G-protein $\beta_{2}$ and $\gamma_{3}$ subunits was highly variable in different cells (Fig. 2C), and this variability complicated the study of $I_{\mathrm{NaP}}$ modulation. One possible source of variability was the requirement for cotransfection of cDNAs encoding three different proteins: the $\mathrm{Na}_{\mathrm{v}} 1.2 \alpha$ subunit, the G-protein $\beta_{2}$ subunit, and the $\gamma$ subunits in all cells $\gamma_{3}$ subunit. To ensure expression of both $G$-protein $\beta$ and G-protein subunits into bicistronic vectors containing an IRES followed by cDNA encoding the yellow or cyan mutants of GFP as reporter genes (Trouet et al., 1997). Control cells transfected with the same fluorescent protein vectors lacking G-protein subunits (Fig. $2 C, \mathrm{CFP}, \mathrm{YFP})$ had $I_{\mathrm{NaP}}$ that was not significantly different from cells transfected with $\mathrm{rNa}_{\mathrm{v}} 1.2$ and $\mathrm{CD} 8\left(\mathrm{CD} 8\right.$, mean $I_{\mathrm{NaP}}=4.5 \pm 0.7 \%$, $n=36$; CFP, YFP, mean $I_{\mathrm{NaP}}=6.8 \pm 1.0 \%, n=20 ; p=0.08$ ) (Fig. $2 C)$. When $\mathrm{G} \beta_{2}$-YFP and $\mathrm{G} \gamma_{3}$-CFP were cotransfected, and only cells clearly fluorescent for both markers were studied, the data were less variable than without use of bicistronic vectors (mean $I_{\mathrm{NaP}}=$ $16 \pm 1.0 \% ; n=26$ ) (Fig. $2 C$, YFP G $\beta_{2}, / \mathrm{CFP} \mathrm{G} \gamma_{3}$ ). Variance of the experimental groups decreased from 92 with CD8 as a reporter to 34 with bicistronic $\mathrm{G} \beta \gamma$ as reporter $\left(p=2 \times 10^{-8}\right)$. As a result of the reduced variability using GFP reporters to monitor expression, smaller numbers of experiments were required to obtain meaningful results when G $\beta \gamma$ coexpression was studied. The IRES vectors were used to verify expression in all additional studies.

\section{Modulation of $I_{\mathrm{NaP}}$ through $\mathrm{rNa}_{\mathrm{v}} 1.2 \mathrm{a}$ channels by $\mathrm{G} \boldsymbol{\beta}_{2}$ subunits alone} To better characterize G $\beta \gamma$ modulation, we examined the ability of single G-protein $\beta$ and $\gamma$ subunits to increase $I_{\mathrm{NaP}}$. Expression of only $\mathrm{G} \beta_{2}$ with $\mathrm{rNa}_{\mathrm{v}} 1.2 \mathrm{a}$ was sufficient to increase $I_{\mathrm{NaP}}$ comparably to that caused by expression of $\mathrm{G} \beta \gamma$ (mean $\left.I_{\mathrm{NaP}}=17 \pm 2 \% ; n=27 ; p=0.00005\right)$ (Fig. $2 C$, YFP, $G \beta_{2}$ ). In contrast, expression of $\mathrm{G} \gamma_{3}$ alone did not modulate $I_{\mathrm{NaP}}$ (mean $I_{\mathrm{NaP}}=7 \pm 1 \% ; n=11 ; p=0.8$ ) (Fig. $2 C$, CFP, $\left.\mathrm{G} \gamma_{3}\right)$. Expression of $\mathrm{G} \beta$ subunits is also sufficient for G-protein modulation of calcium channels (Herlitze et al., 1996). 
Effect of $\mathrm{G} \boldsymbol{\beta}_{2} \gamma_{3}$ on voltage-dependent gating of $\mathrm{rNa}_{\mathrm{v}} 1.2$

We compared the voltage-dependent gating of $I_{\mathrm{NaT}}$ and $I_{\mathrm{NaP}}$ before and after modulation by $\mathrm{G} \beta_{2} \gamma_{3}$. As in previous work (Ma et al., 1997), the major effect of $\mathrm{G} \beta_{2} \gamma_{3}$ on the properties of $\mathrm{rNa}_{\mathrm{v}} 1.2 \mathrm{a}$ was the increase in $I_{\mathrm{NaP}}$. Little change in the voltage dependence of activation of $I_{\mathrm{NaT}}$ was observed (control, $V_{1 / 2}=-5.9 \pm 0.2$ $\mathrm{mV} ; \mathrm{G} \beta_{2} \gamma_{3}, V_{1 / 2}=-7.2 \pm 0.2 \mathrm{mV}$ ) (Fig. $3 A$ ). Coexpression of $\mathrm{G} \beta \gamma$ strikingly increased the amplitude of $I_{\mathrm{NaP}}$ as measured in response to slowly rising voltage ramps (Fig. $3 B$ ), during which $I_{\mathrm{NaT}}$ is inactivated by the slow ramp depolarization. This protocol gives the clearest visual illustration of the large effect of $G \beta \gamma$ coexpression on $I_{\mathrm{NaP}}$. The presence of $I_{\mathrm{NaP}}$ resulted in a biphasic inactivation curve, which was fit by the sum of two Boltzmann relationships (Fig. $3 C$ ). The component of current that had the more positive voltage dependence of inactivation also had slower inactivation kinetics and corresponded to $I_{\mathrm{NaP}}$ (data not shown) (Ma et al., 1997). G $\beta \gamma$ caused an increase in the fraction of current inactivating with the more positive voltage dependence with little change in the voltage dependence of the individual components (Fig. 3C).
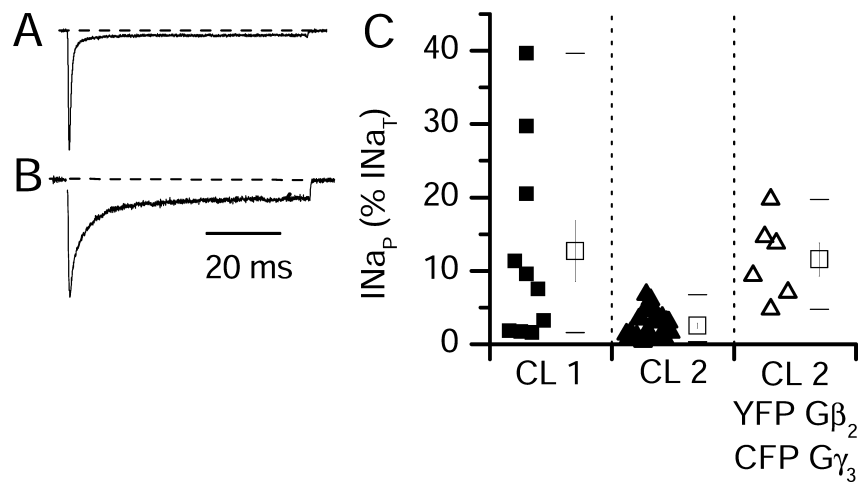

Figure 4. $I_{\text {NaP }}$ conducted by $\mathrm{hNa}_{\mathrm{v}} 1.1$ in two stable cell lines and its modulation by $\mathrm{G}_{2} \gamma_{3}$. $I_{\text {Nap }}$ was measured in two cell lines, CL1 and CL2, stably expressing $\mathrm{hNa}_{\mathrm{v}} 1.1$ and in CL2 transiently transfected with G-protein $\beta_{2}$ and $\gamma_{3}$ subunits. $\boldsymbol{A}$, Current traces from representative cells during depolarizations to $0 \mathrm{mV}$ from a holding potential of $-70 \mathrm{mV}$ from CL2 alone $(A)$ or CL2 cotransfected with $G \beta_{2}$ and $G \gamma_{3}$ subunits $(\boldsymbol{B})$. C, I $I_{\mathrm{NaP}}$ as a percentage of $I_{\mathrm{NaT}}$ in the indicated cells. Values for individual cells are plotted as small symbols; open squares indicate mean \pm SEM. Horizontal bars represent the first and 99 th percentiles of the range.
Modulation of $I_{\mathrm{NaP}}$ conducted by $\mathrm{hNa}_{\mathrm{v}} 1.1$ We were concerned that the large variation in $I_{\mathrm{NaP}}$ among single tsA-201 cells expressing $\mathrm{hNa}_{\mathrm{v}} 1.1$ channels (Fig. 1) might impair measurements of $\mathrm{G} \beta \gamma$ modulation, even using our bicistronic vectors and imaging transfected G $\beta \gamma$. Therefore, we examined the level of $I_{\mathrm{NaP}}$ in two clonal cell lines, derived by stable transfection of $\mathrm{hNa}_{\mathrm{v}} 1.1$ into HEK293 cells (Clare et al., 2000). In the first cell line tested, CL1, the level of $I_{\mathrm{NaP}}$ was similar to that observed after transient transfection of $\mathrm{hNa}_{\mathrm{v}} 1.1$ into tsA201 cells (mean $\left.I_{\mathrm{NaP}}=13 \pm 4 \% ; n=10\right)$ (Fig. 4C). In the second cell line, CL2, lower levels of $I_{\mathrm{NaP}}$ were observed (mean $I_{\mathrm{NaP}}=2.5 \pm 0.4 \% ; n=25$ ) (Fig. $4 A, C$, CL2). These results with two clonal cell lines are consistent with the striking variation of $I_{\mathrm{NaP}}$ among single cells transfected transiently (Fig. 1C).

Because of its low level of intrinsic $I_{\mathrm{NaP}}$ in control, we chose CL2 to study the effect of $\mathrm{G}_{2} \gamma_{3}$ on $\mathrm{I}_{\mathrm{NaP}}$. We cotransfected pG $\beta_{2}$ IRES-YFP and pG $\gamma_{3}$ IRES-CFP into CL2 cells stably expressing $\mathrm{hNa}_{\mathrm{v}} 1.1$. $\mathrm{I}_{\mathrm{NaP}}$ with $\mathrm{G} \beta_{2} \gamma_{3}$ was significantly higher than in untransfected CL2 cells (mean $I_{\mathrm{NaP}}=11 \pm 2 \%$; $n=6 ; p=10^{-7}$ relative to untransfected CL2) (Fig. $4 B, C$, CL2, YFP $\mathrm{G} \beta_{2}$, CFP $\left.\mathrm{G} \gamma_{3}\right)$. Thus, as for $\mathrm{rNa}_{\mathrm{v}} 1.2 \mathrm{a}, I_{\mathrm{NaP}}$ conducted by $\mathrm{hNa}_{\mathrm{v}} 1.1$ is also increased by coexpression of $\mathrm{G} \beta_{2} \gamma_{3}$.

\section{Effect of $\mathrm{G} \boldsymbol{\beta}_{2} \gamma_{3}$ on voltage-dependent gating of $\mathrm{hNa}_{\mathrm{v}} 1.1$}

Cotransfection of hNa 1.1 with $\mathrm{G}_{2} \gamma_{3}$ resulted in a small positive shift in the voltage dependence of activation of $I_{\mathrm{NaT}}$ (Fig. $5 A$ ). Coexpression of $\mathrm{G}_{2} \gamma_{3}$ also substantially increased $I_{\mathrm{NaP}}$ measured using slowly rising voltage ramps (Fig. $5 B$ ). The increased persistent sodium current in cells expressing $\mathrm{G} \beta_{2} \gamma_{3}$ caused a positive shift in the overall inactivation curve, and the baseline of noninactivating current at positive potentials was significantly increased (Fig. 5C). However, as a result of the relatively small level of $I_{\mathrm{NaP}}$ in this cell line, even in the presence of $\mathrm{G} \beta_{2} \gamma_{3}$, the second Boltzmann component from these cells was not as clearly resolved as for $\mathrm{Na}_{\mathrm{v}}$ 1.2. As described above, the relative size of $I_{\mathrm{NaP}}$
B C

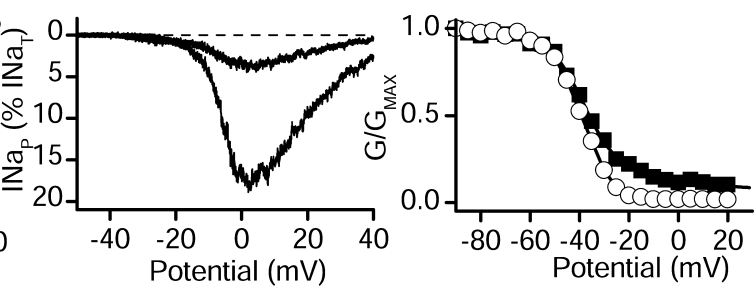

Figure 5. Properties of transient and persistent current in $\mathrm{Na}_{\mathrm{v}} 1.1$ alone and cotransfected with $\mathrm{G} \beta_{2} \gamma_{3}$ as expressed in CL2. $\boldsymbol{A}$, $V_{\mathrm{a}}=-7.5 \pm 0.5 \mathrm{mV}$ and $k=-7.3 \pm 0.4 \mathrm{mV}$; for CL2 cells cotransfected with $\mathrm{G} \beta_{2} \gamma_{3}(n=6), V_{\mathrm{a}}=-3.5 \pm 0.5 \mathrm{mV}$ and $k=$ ( $6.4 \pm 0.4 \mathrm{mV}$. B, Currents elicited by slow $(70 \mathrm{mV} / \mathrm{s})$ voltage ramps from a representative (L2 cell (smaller current) or C, Voltage dependence of inactivation from representative cells, selected to have approximately the mean level of Napr $_{\text {, }}$ determined with $100 \mathrm{~ms}$ prepulses to a variable voltage followed by a test depolarization to $0 \mathrm{mV}$ for CL2 alone (open circles) or CL2 cotransfected with Boltzmann functions to the data were as follows: for $\mathrm{CL2}, V_{1 / 2}=-37.6 \pm 0.1 \mathrm{mV}, k=6.2 \pm 0.1 \mathrm{mV}, C=0.029 \pm 0.003, n=11$; for CL2 cotransfected with $\mathrm{G} \beta_{2} \gamma_{3}, V_{1 / 2}=-34.6 \pm 0.2, k=7.2 \pm 0.2, \mathrm{C}=0.063 \pm 0.003, n=4$.

in tsA-201 cells transiently transfected with $\mathrm{hNa}_{\mathrm{v}} 1.1$ or in cell line $\mathrm{CL} 1$, in which $\mathrm{hNa}_{\mathrm{v}} 1.1$ had been stably expressed in HEK293 cells, was much larger than in CL2. However, the voltagedependent properties of $I_{\mathrm{NaT}}$ and $I_{\mathrm{NaP}}$ in these cells were not different from those of CL2 except for the larger amplitude of $I_{\mathrm{NaP}}$ (data not shown). Thus, for both $\mathrm{hNa}_{\mathrm{v}} 1.1$ and $\mathrm{rNa}_{\mathrm{v}} 1.2 \mathrm{a}$, coexpression of $\mathrm{G} \beta_{2} \gamma_{3}$ increases both the amount of $I_{\mathrm{NaP}}$ relative to $I_{\mathrm{NaT}}$ and the fraction of current with slowed and positive voltagedependent inactivation without major effects on the voltage dependence of activation of $I_{\mathrm{NaT}}$.

\section{Modulation of $I_{\mathrm{NaP}}$ through $\mathrm{rNa}_{\mathrm{v}} 1.4$ and $\mathrm{rNa}_{\mathrm{v}} 1.5$ channels by $\mathrm{G} \boldsymbol{\beta}_{2} \gamma_{3}$}

We tested whether skeletal muscle $\mathrm{rNa}_{\mathrm{v}} 1.4$ and cardiac $\mathrm{rNa}_{\mathrm{v}} 1.5$ channel isoforms were modulated by $\mathrm{G} \beta_{2} \gamma_{3}$ when cotransfected in tsA-201 cells. When transfected alone, $\mathrm{rNa}_{\mathrm{v}} 1.4$ and $\mathrm{rNa}_{\mathrm{v}} 1.5$ give little $I_{\mathrm{NaP}}\left(I_{\mathrm{NaP}}=1.9 \pm 0.4 \%, n=7\right.$; and $2.6 \pm 0.5 \%, n=10$, respectively) (Fig. 6). When $\mathrm{G} \beta_{2} \gamma_{3}$ was coexpressed with either $\mathrm{Na}_{\mathrm{v}} 1.4$ or $\mathrm{Na}_{\mathrm{v}} 1.5$ channels, no significant increase in $I_{\mathrm{NaP}}$ was observed $\left(\mathrm{Na}_{\mathrm{v}} 1.4\right.$ plus $\mathrm{G}_{2} \gamma_{3}, 2.9 \pm 0.6 \%, n=8 ; \mathrm{Na}_{\mathrm{v}} 1.5$ plus 
A

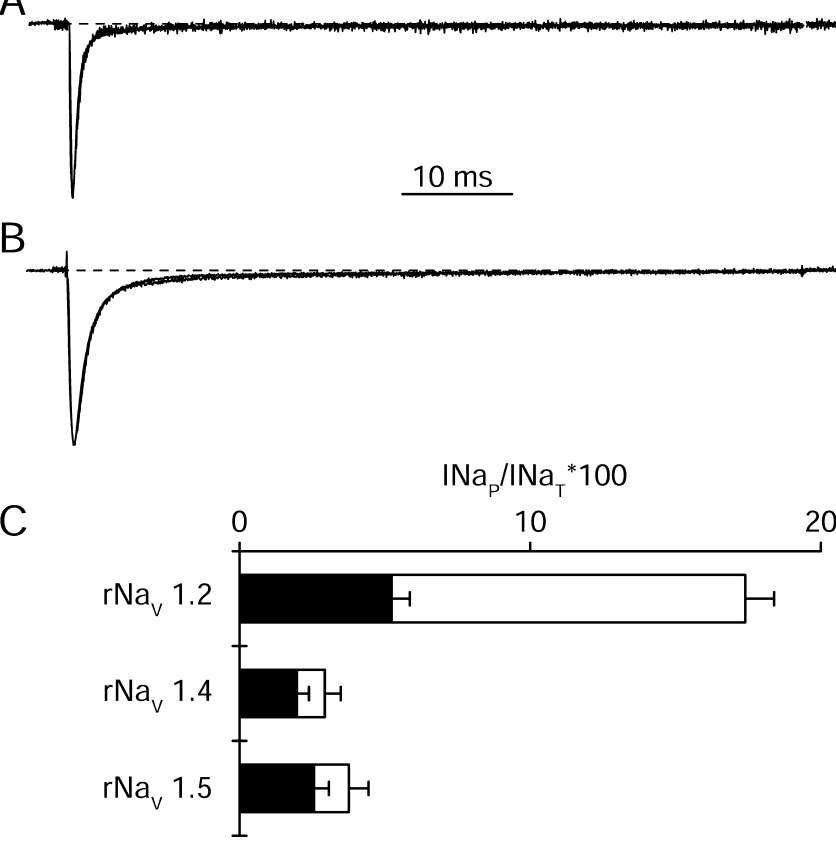

Figure 6. A, Normalized superimposed current traces from two representative tsA-201 cells transfected with $\mathrm{rNa}_{\mathrm{v}} 1.4$ alone or cotransfected with $\mathrm{G} \beta_{2}$ and $\mathrm{G} \gamma_{3}$. Currents were elicited by a depolarization to $0 \mathrm{mV}$ from a holding potential of $-70 \mathrm{mV}$. $\boldsymbol{B}$, Normalized superimposed current traces from two representative tsA-201 cells transfected with $\mathrm{rNa}_{\mathrm{v}} 1.5$ alone or cotransfected with $\mathrm{G} \beta_{2}$ and $\mathrm{G} \gamma_{3}$. Currents were elicited by a depolarization to $-10 \mathrm{mV}$ from a holding potential of $-70 \mathrm{mV}$. C, Bar graph showing $I_{\mathrm{Nap}}$ as percentage of $I_{\mathrm{NaT}}$ for cells transfected with the indicated sodium channel $\alpha$ subunit alone (black bars) or in combination with $\mathrm{G} \beta_{2}$ and $\mathrm{G} \gamma_{3}$ (open bars). For r $\mathrm{raa}_{\mathrm{v}} 1$.2a: control (pooled data), $I_{\mathrm{NaP}}=5.3 \pm 0.6 \%, n=56$; plus $\mathrm{G}_{2} \gamma_{3}$, $I_{\mathrm{NaP}}=16 \pm 1.0 \%, n=26$. For r Na 1 1.4: control, $I_{\mathrm{NaP}}=1.9 \pm 0.4 \%, n=7 ;$ plus $G \beta_{2} \gamma_{3}, 2.9 \pm$ $0.6 \%, n=8$. For rNa 1.5 : control, $2.6 \pm 0.5 \%, n=10$; plus $\mathrm{G}_{2} \gamma_{3}, 3.7 \pm 0.7 \%, n=5$. Error bars represent SEM.

$\mathrm{G} \beta_{2} \gamma_{3}, 3.7 \pm 0.7 \%, n=5$ ) (Fig. 6). Thus, little $I_{\mathrm{NaP}}$ is produced by these two isoforms, and it is not increased by coexpression of $\mathrm{G} \beta_{2} \gamma_{3}$.

\section{Modulation of $I_{\mathrm{NaP}}$ by the CT domains of $\mathrm{rNa}_{\mathrm{v}} 1.4$ and $\mathrm{rNa}_{\mathrm{v}} 1.5$ channels}

We proposed previously that the CT of $\mathrm{rNa}_{\mathrm{v}} 1.2 \mathrm{a}$ is a domain required to produce $I_{\mathrm{NaP}}$ in that channel (Ma et al., 1997). To test this, we used the construct $\mathrm{Na}_{\mathrm{v}}$ 1.2/1.5 CT (Mantegazza et al., 2001). In this construct, the $\mathrm{rNa}_{\mathrm{v}} 1.5$ CT beginning with E1755 replaced the CT of $\mathrm{rNa}_{\mathrm{v}} 1.2 \mathrm{a}$, which had been truncated before E1777. This chimeric mutation did not increase $I_{\mathrm{NaP}}$ in the absence of modulation by G $\beta \gamma$ (Fig. 7). However, the chimera was strongly modulated by $\mathrm{G} \beta_{2} \gamma_{3}$ (Fig. 7). Thus, although the CT of $\mathrm{Na}_{\mathrm{v}} 1.5$ does not produce modulation when attached to its native subunit, it produces strong modulation of $\mathrm{rNa}_{\mathrm{v}} 1.2 \mathrm{a}$.

This contrasts with the effects observed in chimeras of $\mathrm{rNa}_{\mathrm{v}} 1.4$ and $\mathrm{rNa}_{\mathrm{v}} 1.2 \mathrm{a}$, in which the CT of $\mathrm{rNa}_{\mathrm{v}} 1.2 \mathrm{a}$ was completely or partially replaced by the analogous sequence from $\mathrm{Na}_{\mathrm{v}} 1.4$. In $\mathrm{Na}_{\mathrm{v}} 1.2 / 1.4 \mathrm{CT}$, the $\mathrm{rNa}_{\mathrm{v}} 1.4$ CT beginning with E1592 replaced the CT of $\mathrm{rNa}_{\mathrm{v}} 1.2 \mathrm{a}$, which had been truncated before E1777. Substitution of the C terminus in $\mathrm{Na}_{\mathrm{v}}$ 1.2/1.4 CT did not significantly change the level of $I_{\mathrm{NaP}}$ under control conditions. In addition, there was no increase after coexpression of $\mathrm{G} \beta_{2} \gamma_{3}$ (Fig. 7). Thus, the $\mathrm{Na}_{\mathrm{v}} 1.4 \mathrm{C}$ terminus does not support modulation by $\mathrm{G} \beta \gamma$. These findings are consistent with the CT domains of $\mathrm{Na}_{\mathrm{v}} 1.2$ and $\mathrm{Na}_{\mathrm{v}} 1.5$ containing molecular determinants required for modulation of $I_{\mathrm{NaP}}$ by $\mathrm{G} \beta \gamma$ that are absent in the $\mathrm{Na}_{\mathrm{v}} 1.4 \mathrm{CT}$.

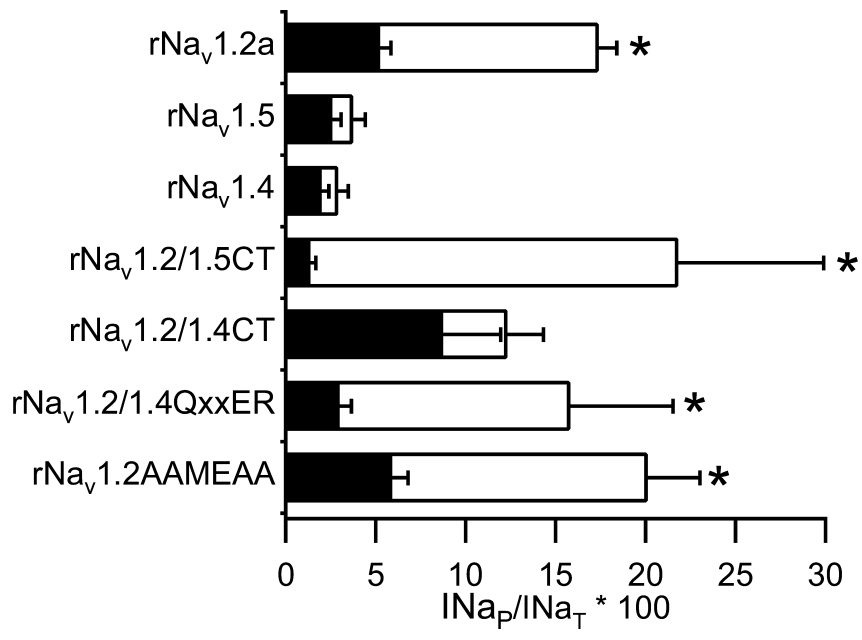

Figure 7. $I_{\text {NaP }}$ in sodium channels containing mutations affecting the QXXER motif and their modulation by $\mathrm{G}$-protein $\beta \gamma$ subunits. Bar graph showing $I_{\mathrm{NaP}}$ as percentage of $I_{\mathrm{NaT}}$ for cells transfected with the indicated sodium channel $\alpha$ subunit alone (black bars) or in combination with $\mathrm{G} \beta_{2}$ and $\mathrm{G} \gamma_{3}$ (open bars). For $r \mathrm{ra}_{\mathrm{v}} 1.2 \mathrm{a}, \mathrm{rNa} \mathrm{v}_{\mathrm{v}} 1.4$, and $\mathrm{rNa}_{\mathrm{v}} 1.5$, see Figures 2 and 6 for mean values and errors. For $\mathrm{Na}_{v} 1.2 \mathrm{a} / 1.5 \mathrm{CT}$ : control, $I_{\mathrm{NaP}}=1.4 \pm 0.3, n=7 ; \mathrm{G} \beta_{2} \gamma_{3}, I_{\mathrm{NaP}}=21.8 \pm$ $8.1, n=5$. For $\mathrm{Na}_{\mathrm{v}} 1.2 \mathrm{a} / 1.4 \mathrm{CT}$ : control, $I_{\mathrm{NaP}}=8.7 \pm 3.2, n=8 ; \mathrm{G} \beta_{2} \gamma_{3}, I_{\mathrm{NaP}}=12 \pm 2, n=$ 12. For r $\mathrm{Na}_{\mathrm{v}}$ 1.2/1.40xxER: control, $I_{\mathrm{NaP}}=3.0 \pm 0.7, n=9 ; G \beta_{2} \gamma_{3}, I_{\mathrm{NaP}}=16 \pm 6, n=5$. For $\mathrm{rNa}_{\mathrm{v}}$ 1.2a/AAMEAA: control, $I_{\mathrm{NaP}}=5.9 \pm 0.9, n=10 ; \mathrm{G} \beta_{2} \gamma_{3}, I_{\mathrm{NaP}}=20 \pm 3, n=7$. Error bars represent SEM. Asterisks indicate significant modulation by $\mathrm{GB}_{2} \gamma_{3}(p<0.05)$.

\section{Requirement for the $\mathrm{rNa}_{\mathrm{v}} 1.2 \mathrm{a} \mathrm{CT}$ and its $\mathrm{QxxER}$ motif for modulation by $\mathrm{G} \boldsymbol{\beta} \gamma$}

A short sequence motif ( $\mathrm{QxxER}$ ) in the $\mathrm{Na}_{\mathrm{v}} 1.2 \mathrm{a} C \mathrm{CT}$ was suggested initially to be an important molecular determinants of $\mathrm{G} \beta \gamma$ modulation based on our finding that a peptide containing this motif effectively inhibited G-protein modulation (Ma et al., 1997). A QxxER motif is conserved in $\mathrm{hNa}_{\mathrm{v}} 1.1$, partially conserved in $\mathrm{rNa}_{\mathrm{v}} 1.5$, but absent in the CT of $\mathrm{rNa}_{\mathrm{v}} 1.4$. To assess the role of the QxxER region of $\mathrm{rNa}_{\mathrm{v}} 1.2 \mathrm{a}$ in modulation by $\mathrm{G} \beta_{2} \gamma_{3}$, we constructed two mutant channels. For the first, we used the CT of $\mathrm{Na}_{\mathrm{v}} 1.4$ to replace the QxxER sequence in the CT of $\mathrm{Na}_{\mathrm{v}} 1.2 \mathrm{a}$, because $\mathrm{Na}_{\mathrm{v}} 1.4$ did not support modulation by $\mathrm{G} \beta \gamma$. In $\mathrm{Na}_{\mathrm{v}} 1.2$ / 1.4QxxER, the $\mathrm{Na}_{\mathrm{v}} 1.4 \mathrm{CT}$ from K1691 to K1697 replaced the QxxER region in $\mathrm{rNa}_{\mathrm{v}} 1.2 \mathrm{a}$ CT from R1876 and R1882. In the second construct, $\mathrm{Na}_{\mathrm{v}} 1.2 /$ AAMEAA, I1875, Q1876, E1879, and $\mathrm{R} 1880$ in $\mathrm{rNa}_{\mathrm{v}} 1.2 \mathrm{a}$ were replaced with alanines, thus removing the specific side chains of the critical amino acids in the QxxER motif. Both $\mathrm{Na}_{\mathrm{v}} 1.2 / 1.4$ QxxER and $\mathrm{Na}_{\mathrm{v}} 1.2 /$ AAMEAA were modulated fully by $\mathrm{G} \beta_{2} \gamma_{3}$ (Fig. 7), indicating that this motif is not necessary for modulation of $\mathrm{Na}_{\mathrm{v}} 1.2$ by $\mathrm{G} \beta \gamma$. Molecular determinants for modulation of $\mathrm{Na}_{\mathrm{v}} 1.2$ a sodium channel by $\mathrm{G} \beta \gamma$ must reside in other regions of the $\mathrm{Na}_{\mathrm{v}} 1.2 \mathrm{CT}$ that have amino acid sequence differences from the $\mathrm{Na}_{\mathrm{v}} 1.4 \mathrm{CT}$.

\section{Requirement for the last 28 amino acids of $\mathrm{rNa}_{\mathrm{v}} 1.2 \mathrm{a} \mathrm{CT}$ for modulation by $\mathrm{G} \boldsymbol{\beta} \gamma$}

To localize the molecular determinants in the $\mathrm{CT}$ responsible for $I_{\mathrm{NaP}}$ and its modulation by $\mathrm{G} \beta \gamma$, we used a series of $\mathrm{rNa}_{\mathrm{v}} 1.2 \mathrm{a}$ mutants in which the CT was truncated at different positions, as described previously (Mantegazza et al., 2001). Mutants that were truncated on the N-terminal side of K1890 did not express measurable sodium current or gave rise to currents that were too small to study (Mantegazza et al., 2001). Therefore, we only tested mutants in which the truncation was on the C-terminal side of K1890. Although the mean level of $I_{\mathrm{NaP}}$ in the absence of transfected $G \beta \gamma$ subunits varied among the truncation mutants, the 
differences from wild type (WT) were not significant $(p>0.05)$ (Fig. 8). However, the effects of cotransfected $\mathrm{G} \beta \gamma$ on these mutant channels differed significantly. Coexpression of $\mathrm{G} \beta_{2} \gamma_{3}$ did not significantly increase $I_{\mathrm{NaP}}$ when the channel was shortened beyond T1951 in mutants $\Delta \mathrm{K} 1890, \Delta \mathrm{K} 1909, \Delta \mathrm{K} 1929$, and $\Delta \mathrm{T} 1951$ (Fig. 8, bars lacking asterisks). In constructs with longer $\mathrm{C}$ termini, including $\Delta \mathrm{S} 1977$ and $\Delta \mathrm{K} 1998, I_{\mathrm{NaP}}$ was increased significantly by $\mathrm{G} \beta_{2} \gamma_{3}$ coexpression (Fig. 8 , bars with asterisks). However, the increase of $I_{\mathrm{NaP}}$ caused by G $\beta_{2} \gamma_{3}$ coexpression with $\Delta \mathrm{S} 1977$ and $\Delta \mathrm{K} 1998$ was not as large as for $\mathrm{WT} \mathrm{rNa}_{\mathrm{v}} 1.2$, as denoted by the bars labeled with \#. The pattern of decreased modulation by $\mathrm{G} \beta \gamma$ in these deletion constructs suggests that the amino acid residues between positions 1951 and 1977 and between position 1977 and the C terminus of the protein at position 2005 are important for modulation by $\mathrm{G} \beta \gamma$.

To test the functional role of the final 28 amino acid residues directly, we constructed the mutant $\mathrm{Na}_{\mathrm{v}} 1.2 \mathrm{a} / \Delta 1891-1977$, in which amino acid residues from V1891 to $\mathrm{S} 1977$ were deleted. This is equivalent to $\mathrm{Na}_{\mathrm{v}} 1.2 \mathrm{a} / \Delta \mathrm{K} 1890$ having the last 28 amino acids of the $\mathrm{C}$ terminal added directly to it. Modulation of this construct by $\mathrm{Na}_{\mathrm{v}} 1.2 \mathrm{a} / \Delta 1891-1977$ was similar to modulation of the WT Na $1.2 \mathrm{a}$ channel (Fig. 8). Thus, the last 28 amino acids of the CT are necessary for modulation by $\mathrm{G} \beta \gamma$ and are sufficient to replace the requirement for the remainder of the distal half of the C-terminal domain.

\section{Voltage-dependent gating and modulation of $\mathrm{Na}_{\mathbf{v}} 1.2 \Delta 1891-1977$}

We analyzed the functional properties of $\mathrm{Na}_{\mathrm{v}} 1.2 \Delta 1891-1977$ more completely and compared them with WT. Coexpression of $\mathrm{G} \beta_{2} \gamma_{3}$ increased $I_{\mathrm{NaP}}$ during single depolarizations (Fig. 9A,B) or during slow voltage ramps (Fig. $9 C, D$ ). The voltage dependence of activation of $I_{\mathrm{NaT}}$ conducted by $\mathrm{Na}_{\mathrm{v}} 1.2 \mathrm{a} / \Delta 1891-1977$ was unchanged from that of wild-type $\mathrm{Na}_{\mathrm{v}} 1.2 \mathrm{a}$, and, as for WT, cotransfection of $\mathrm{G} \beta \gamma$ caused little change in the voltage dependence of activation (Fig. 9E). The voltage dependence of inactivation was shifted $\sim 10 \mathrm{mV}$ more negative than for $\mathrm{WT} \mathrm{Na}_{\mathrm{v}} 1.2 \mathrm{a}$. This is consistent with previous findings implicating the $\mathrm{C}$-terminal region of the sodium channel in modulating inactivation (Deschenes et al., 2001; Mantegazza et al., 2001; Cormier et al., 2002; Motoike et al., 2004). Cotransfection of $\mathrm{G}_{2} \gamma_{3}$ subunits with $\mathrm{Na}_{\mathrm{v}} 1.2 \mathrm{a} / \Delta 1891-1977$ did not appreciably change the negative component of the steady-state inactivation curve but increased the amplitude of a more positive component of inactivation (Fig. $9 F$, closed squares), similar to $\mathrm{G} \beta \gamma$ modulation of WT. Thus, although the deletion in $\mathrm{Na}_{\mathrm{v}} 1.2 \mathrm{a} / \Delta 1891-$ 1977 causes a negative shift in the voltage dependence of inactivation of $I_{\mathrm{NaT}}$ under control conditions, $I_{\mathrm{NaP}}$ is modulated essentially normally by cotransfection of $\mathrm{G} \beta_{2} \gamma_{3}$.

\section{Comparison of the amino acid sequences of the distal} C-terminal domains of $\mathrm{Na}_{\mathrm{v}} 1$ channels

Because the distal CT of $\mathrm{Na}_{\mathrm{v}} 1.1$ and $\mathrm{Na}_{\mathrm{v}} 1.2$ can support modulation by $\mathrm{G} \beta \gamma$, but the CT of $\mathrm{Na}_{\mathrm{v}} 1.4$ cannot, it is interesting to

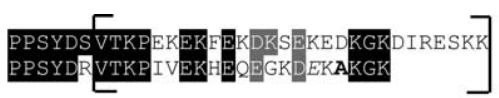

$$
\begin{aligned}
& \text { Nav1.2 } \\
& \text { Nav1. } 4 \\
& \text { Nav1. } 5
\end{aligned}
$$

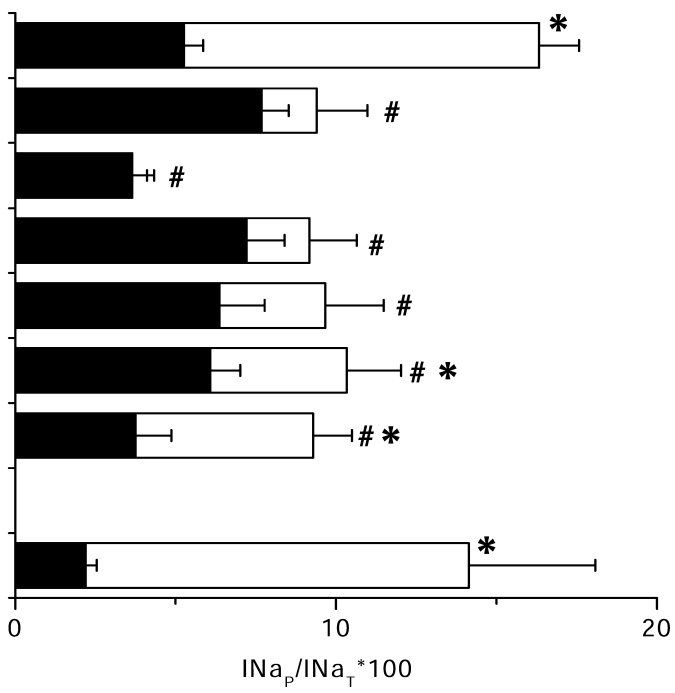

Figure 8. $I_{\mathrm{NaP}}$ in truncated $\mathrm{Na}_{\mathrm{v}} 1$.2a channels and its modulation by $\mathrm{G}$-protein $\beta_{2} \gamma_{3}$ subunits. Left, Diagram of the CT of the

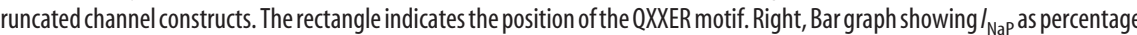
modulation by $\mathrm{G} \beta \gamma$ that is significantly reduced when compared with modulation of the full-length channel ( $p<$

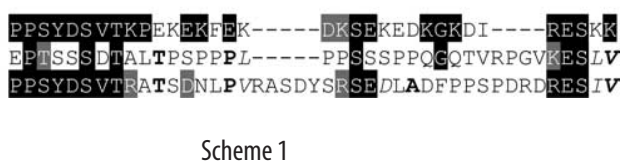

compare the amino acid sequences of the distal CT showing the identities (black blocks) and similarities (gray blocks) to $\mathrm{Na}_{\mathrm{v}} 1.2 \mathrm{a}$, as follows:

$\mathrm{Na}_{\mathrm{v}} 1.1$ is quite similar to $\mathrm{Na}_{\mathrm{v}} 1.2$ but is seven amino acids shorter. Among the 21 aligned amino acid residues, 10 are identical, two are similar, and there are no gaps. In contrast, $\mathrm{Na}_{\mathrm{v}} 1.4$ has only five identical and one similar residues, and a four-residue gap in $\mathrm{Na}_{\mathrm{v}} 1.2$ is required for alignment. $\mathrm{Na}_{\mathrm{v}} 1.5$ has seven identical and three similar residues but requires gaps of four and five residues in $\mathrm{Na}_{\mathrm{v}} 1.2$ for alignment. Thus, the similarities of the $\mathrm{Na}_{\mathrm{v}} 1.1$ and $\mathrm{Na}_{\mathrm{v}} 1.2$ sequences support a common function for their distal C-terminal segments, whereas the differences in sequence of $\mathrm{Na}_{\mathrm{v}} 1.5$ and especially $\mathrm{Na}_{\mathrm{v}} 1.4$ C-terminal sequences suggest different functions. Additional experiments will be required to determine whether these segments play important roles in some aspect of G-protein modulation of cardiac and skeletal muscle sodium channels.

\section{Discussion}

\section{Persistent sodium current in neurons}

$I_{\mathrm{NaP}}$ is implicated in many aspects of neuronal function, including shaping bursting behavior, controlling firing frequency, integrating synaptic input, and generating epileptiform hyperexcit- 

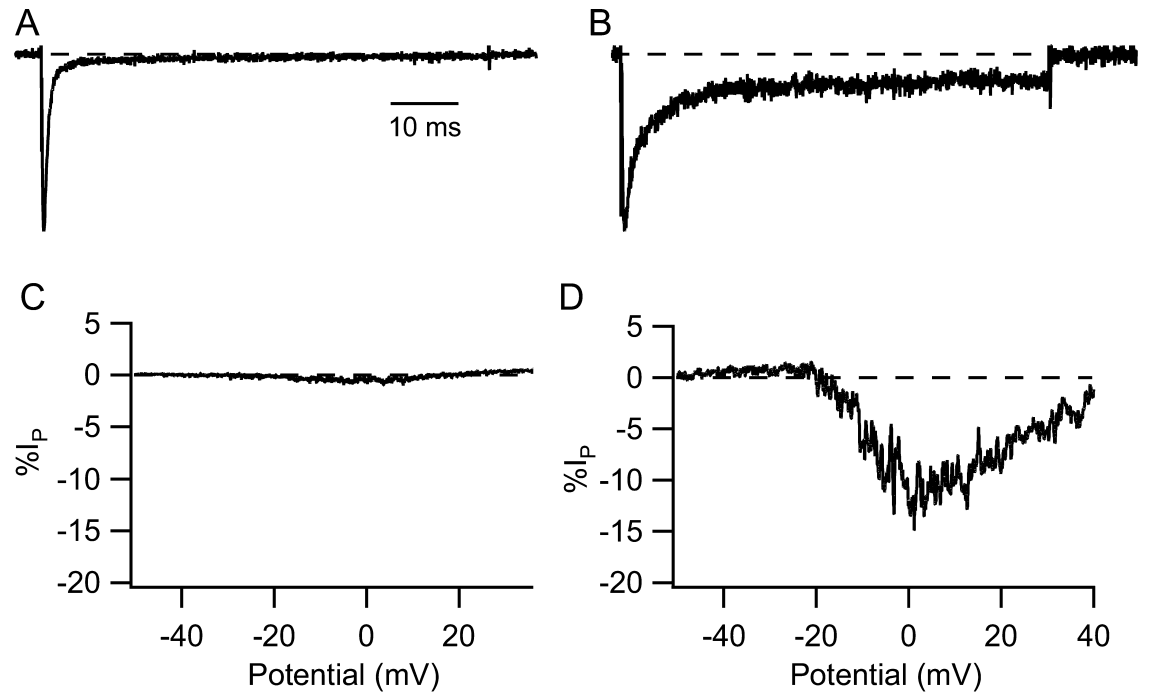

$\mathrm{E}$

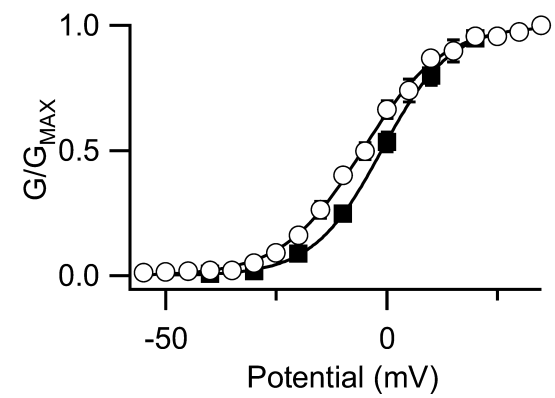

D

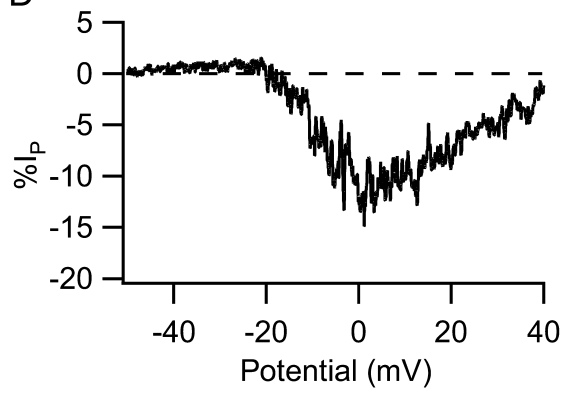

$\mathrm{F}$

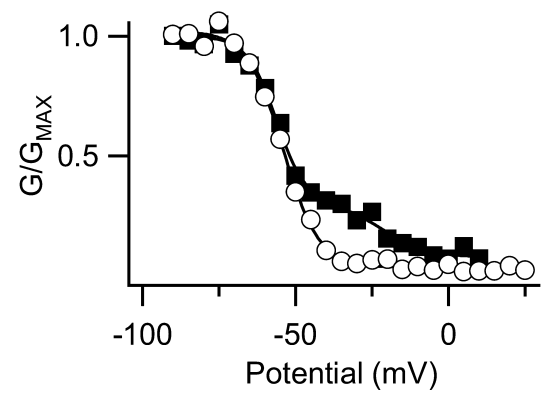

Figure 9. Modulation of $\mathrm{rNa}_{\mathrm{v}} 1.2 \mathrm{a} / 1891 \Delta 1977$ channels by $\mathrm{G}$-protein $\beta$ $\gamma$ subunits. $\boldsymbol{A}, \boldsymbol{B}$, Examples of representative current traces during depolarizations to $0 \mathrm{mV}$ from a holding potential of $-70 \mathrm{mV}$ from a cell expressing $\mathrm{rNa} \mathrm{v}_{\mathrm{v}} 1.2 \mathrm{a} / 1891 \Delta 1977$ channels alone $(\boldsymbol{A})$ and from a cell coexpressing $\mathrm{rNa}_{\mathrm{v}} 1.2 \mathrm{a} / 1891 \Delta 1977$ and $\mathrm{G} \beta_{2} \gamma_{3}(\boldsymbol{B})$. C, $\boldsymbol{D}$, Currents in response to voltage ramps at 70 $\mathrm{mV} / \mathrm{s}$ from -60 to $+40 \mathrm{mV}$ from the same cells shown in $\boldsymbol{A}$ and $\boldsymbol{B}$, respectively. $\boldsymbol{E}$, Mean voltage dependence of activation for cells transfected with $\mathrm{rNa}_{\mathrm{v}} 1.2 \mathrm{a} / 1891 \Delta 1977$ channels alone (open circles) and cotransfected with $\mathrm{G} \beta_{2} \gamma_{3}$ (filled squares). The solid lines are fits of a Boltzmann equation to the mean data. For $\mathrm{rNa}_{\mathrm{v}} 1.2 \mathrm{a} / 1891 \Delta 1977$ : control, $V_{1 / 2}=-5.6 \pm 1.10 \mathrm{mV}, k=$ $-8.6 \pm 0.47 \mathrm{mV}, n=9$; plus $\mathrm{G}_{2} \gamma_{3}, V_{1 / 2}=-0.1 \pm 1.55 \mathrm{mV}$ and $k=-8.5 \pm 0.48 \mathrm{mV}, n=7$. $\boldsymbol{F}$, Voltage dependence of inactivation from a representative cell transfected with $\mathrm{rNa}_{\mathrm{v}} 1$.2a/1891 1977 channels alone (open circles) and cotransfected with $\mathrm{G} \beta_{2} \gamma_{3}$ (filled squares). Representative cells were chosen to have approximately the mean level of $I_{\mathrm{NaP}}$. Mean parameters derived from fits of Boltzmann functions to the data were for $\mathrm{rNa}_{\mathrm{v}} 1$.2a/1891 1977 : control, $V_{1 / 2}=-54.5 \pm 0.15 \mathrm{mV}, k=$ $6.3 \pm 0.13 \mathrm{mV}, \mathrm{C}=0.04 \pm 0.002, n=8$; plus $\mathrm{G}_{2} \gamma_{3}$ (fit with 2 Boltzmann components), $V_{1 / 2,1}=-54.5 \pm 0.52 \mathrm{mV}, k_{1}=$ $4.0 \pm 0.80 \mathrm{mV}, A 2=0.43, V_{1 / 2,2}=-50.8 \pm 2.89, k_{2}=15.7 \pm 2.67 \mathrm{mV}, \mathrm{C}=0.03 \pm 0.008, n=3$.

ability (see Introduction). $I_{\mathrm{NaP}}$ is thought to be conducted by the same sodium channels that generate $I_{\mathrm{NaT}}$ in some neurons (Alzheimer et al., 1993; Taddese and Bean, 2002), but the sodium channel subtypes that generate $I_{\mathrm{NaP}}$ and the mechanisms that regulate $I_{\mathrm{NaT}}$ versus $I_{\mathrm{NaP}}$ in neurons are unknown. Here, we have addressed this gap in knowledge by analyzing the level of $I_{\mathrm{NaP}}$ generated by different sodium channel subtypes, demonstrating subtype-selective effects of $\mathrm{G} \beta \gamma$ subunits on $I_{\mathrm{NaP}}$ and identifying an essential molecular determinant of $\mathrm{G} \beta \gamma$ modulation of $\mathrm{Na}_{\mathrm{v}} 1.2$ channels.

\section{Different levels of persistent sodium current conducted by sodium channel subtypes}

Our results show that different sodium channel $\alpha$ subunits intrinsically generate different levels of $I_{\mathrm{NaP}} \cdot \mathrm{Na}_{\mathrm{v}} 1.1$ and $\mathrm{Na}_{\mathrm{v}} 1.2$ both conduct substantial $I_{\mathrm{NaP}}$, but when expressed transiently in tsA-201 cells, $\mathrm{Na}_{\mathrm{v}} 1.1$ produces significantly more $I_{\mathrm{NaP}}$ than $\mathrm{Na}_{\mathrm{v}}$ 1.2. Conversely, $\mathrm{Na}_{\mathrm{v}} 1.4$ and $\mathrm{Na}_{\mathrm{v}} 1.5$ conduct little $I_{\mathrm{NaP}}$. Although the CT has been implicated in the modulation of $I_{\mathrm{NaP}}$ by $\mathrm{G} \beta \gamma$ (Ma et al., 1997; this work) and in setting the different inactivation properties of $\mathrm{Na}_{\mathrm{v}} 1.5$ relative to $\mathrm{Na}_{\mathrm{v}} 1.2 \mathrm{a}$ or $\mathrm{Na}_{\mathrm{v}} 1.4$ channels (Mantegazza et al., 2001; Deschenes et al., 2001; Cormier et al., 2002; Motoike et al., 2004), the CT of $\mathrm{Na}_{\mathrm{v}} 1.4$ did not reduce $I_{\mathrm{NaP}}$ produced by the $\mathrm{Na}_{\mathrm{v}} 1.2 \mathrm{a}$ in chimera $\mathrm{Na}_{\mathrm{v}} 1.2 / 1.4 \mathrm{CT}$. Thus, the intrinsic level of $I_{\mathrm{NaP}}$ is determined by the pre-CT portion of the channel rather than by the CT. However, the CT alters modulation of $I_{\mathrm{NaP}}$ when attached to a sodium channel that conducts substantial $I_{\mathrm{NaP}}$.

\section{Regulation of persistent sodium currents by G-proteins}

Although $I_{\mathrm{NaP}}$ is important physiologically, few experimental conditions have been identified that alter $I_{\mathrm{NaP}}$ relative to $I_{\mathrm{NaT}}$. We showed previously that coexpression of G-protein $\beta \gamma$ subunits can substantially increase $I_{\mathrm{NaP}}$, relative to $I_{\mathrm{NaT}}$, and we implicated the CT of the $\mathrm{Na}_{\mathrm{v}} 1.2$ channel $\alpha$ subunit in those effects by demonstrating block of $I_{\mathrm{NaP}}$ by a competing CT peptide (Ma et al., 1997). Our present results extend those findings in three important respects. First, using bicistronic vectors and fluorescence to verify expression of $\mathrm{G} \beta$ and $\mathrm{G} \gamma$, we substantially reduced cell-to-cell variability in $\mathrm{G} \beta \gamma$ modulation of $I_{\mathrm{NaP}}$, thereby providing stronger evidence that $\mathrm{G} \beta \gamma$ subunits are important regulators of $I_{\mathrm{NaP}}$. Second, with this improved assay, we identified a novel subtype specificity for $\mathrm{G} \beta \gamma$ modulation of $I_{\mathrm{NaP}}$. G $\beta \gamma$ subunits can regulate $I_{\mathrm{NaP}}$ of $\mathrm{Na}_{\mathrm{v}} 1.1$ and $\mathrm{Na}_{\mathrm{v}} 1.2$ channels but not of $\mathrm{Na}_{\mathrm{v}} 1.4$ or $\mathrm{Na}_{\mathrm{v}} 1.5$ channels. However, the CT of $\mathrm{Na}_{\mathrm{v}} 1.5$, but not that of $\mathrm{Na}_{\mathrm{v}} 1.4$, can support modulation by $\mathrm{G} \beta_{2} \gamma_{3}$ when attached to $\mathrm{Na}_{\mathrm{v}} 1.2 \mathrm{a}$. The ability of the $\mathrm{Na}_{\mathrm{v}} 1.5$ CT to support modulation when incorporated in a chimera with $\mathrm{Na}_{\mathrm{v}} 1.2 \mathrm{a}$ but not in $\mathrm{Na}_{\mathrm{v}} 1.5$ highlights the importance of the pre-CT portion of the channel in permitting modulation by $\mathrm{G} \beta \gamma$ acting via the CT. Finally, our improved methods allowed analysis of deletion mutants to directly identify the site of $\mathrm{G} \beta \gamma$ action in the CT. Surprisingly, these results implicate the final 28 amino acids of $\mathrm{Na}_{\mathrm{v}} 1.2$ in $\mathrm{G} \beta \gamma$ binding and regulation. We propose that this short segment forms part of the $\mathrm{G} \beta \gamma$ interaction site and plays an important role in modulation of channel gating.

G $\beta \gamma$ subunits do not greatly alter the voltage dependence of activation or inactivation of $I_{\mathrm{NaT}}$. In contrast, the voltage dependence of inactivation of $I_{\mathrm{NaP}}$ is shifted positively with respect to $I_{\mathrm{NaT}}$. These results are consistent with a mechanism in which $\mathrm{G} \beta \gamma$ generates $I_{\mathrm{NaP}}$ by destabilizing fast inactivation and switching a fraction of sodium channels to a noninactivating gating mode with slowed and positively shifted inactivation (Ma et al., 1997). The molecular basis for this might be $G \beta \gamma$-induced destabilization of binding of the inactivation gate to its receptor.

\section{Molecular determinants of G $\boldsymbol{\beta} \gamma$ modulation in the C terminus}

Ma et al. (1997) proposed that G $\beta \gamma$ bound to the CT of the $\mathrm{Na}_{\mathrm{v}} 1.2$ channel to modulate $I_{\mathrm{NaP}}$, because its effect was blocked 
by a peptide containing the QMEER sequence of the CT. Recent biochemical evidence shows that $\mathrm{G} \beta \gamma$ indeed binds to $\mathrm{Na}_{\mathrm{v}} 1.2$ sodium channel $\alpha$ subunits (Marin et al., 2001) and to the CT of the $\mathrm{Na}_{\mathrm{v}} 1.3 \alpha$ subunit (Lenkowski et al., 2004). These findings are consistent with an essential role for the CT in G $\beta \gamma$ modulation of $I_{\mathrm{NaP}}$. Peptides containing a similar QxxER motif reduced $\mathrm{G} \beta \gamma$ modulation of other target proteins, including calcium channels (Chen et al., 1995; Herlitze et al., 1997; Zamponi et al., 1997). Such peptides are expected to bind G $\beta \gamma$ subunits and inhibit their action. However, we show that the QxxER motif is unnecessary for modulation of $\mathrm{Na}_{\mathrm{v}} 1.2$ by coexpressed $\mathrm{G} \beta \gamma$. Perhaps the QxxER motif tethers and localizes G-protein $\beta \gamma$ subunits near their site of action in high local concentration, enhancing G $\beta \gamma$ effects at low levels of G-protein activation.

Our results show that the last 28 amino acids of $\mathrm{rNa}_{\mathrm{v}} 1.2$ are necessary for $\mathrm{G} \beta \gamma$ modulation of $\mathrm{Na}^{+}$channels. Modulation was lost when the CT of $\mathrm{rNa}_{\mathrm{v}} 1.2 \mathrm{a}$ was replaced with that of $\mathrm{rNa}_{\mathrm{v}} 1.4$ or when the CT of $\mathrm{Na}_{\mathrm{v}} 1.2$ was truncated at K1890. Addition of only the last 28 amino acids of the $\mathrm{rNa}_{\mathrm{v}} 1.2 \mathrm{a}$ CT to this mutant restored $\mathrm{G} \beta \gamma$ modulation. Thus, these 28 residues are sufficient for modulation of $\mathrm{rNa}_{\mathrm{v}} 1.2 \mathrm{a}$ by $\mathrm{G} \beta \gamma$, and the intervening residues between K1890 and S1977 are unnecessary.

The distal CTs of sodium channels contain other motifs of potential importance in regulation of channel function, localization, and degradation. An IQ domain starting at position 1912 in $\mathrm{Na}_{\mathrm{v}} 1.2$ has been implicated in interactions of calmodulin with several sodium channel isoforms (Deschenes et al., 2002; Tan et al., 2002; Herzog et al., 2003; Kim et al., 2004). Just N-terminal to the site of G-protein regulation, a sequence (PPSY) is implicated in interaction of Nedd 4 ubiquitin ligase and is present in $\mathrm{Na}_{\mathrm{v}} 1.1$, $\mathrm{Na}_{\mathrm{v}} 1.2$, and $\mathrm{Na}_{\mathrm{v}} 1.5$ but not in $\mathrm{Na}_{\mathrm{v}} 1.4$ (van Bemmelen et al., 2004). In addition, the final three amino acids of $\mathrm{Na}_{\mathrm{v}} 1.4$ and $\mathrm{Na}_{\mathrm{v}} 1.5$ are potential interaction sites for PDZ (postsynaptic density-95/Discs large/zona occludens-1) proteins such as the syntrophin family of dystrophin-associated proteins, which may contribute to channel localization in cardiac and skeletal muscle (Gee et al., 1998). These processes could potentially interact with regulation by $\mathrm{G}$-proteins.

\section{Comparison of regulation of $I_{\mathrm{NaP}}$ in transfected cells and neurons}

$I_{\mathrm{NaP}}$ in neurons is generally smaller than $I_{\mathrm{NaP}}$ in transfected tsA201 cells, even without modulation by G $\beta \gamma$. The ratio of $I_{\mathrm{NaP}}$ to $I_{\mathrm{NaT}}$ reported here would probably be incompatible with normal neuronal function in vivo (Kearney et al., 2001). Evidently, other regulation in neurons limits $I_{\mathrm{NaP}}$. Nevertheless, $I_{\mathrm{NaP}}$ in neurons resembles $I_{\mathrm{NaP}}$ produced by $\mathrm{G} \beta \gamma$ in transfected cells in several respects. Activation of $I_{\mathrm{NaP}}$ of sodium channels expressed in tsA201 cells is shifted negatively relative to $I_{\mathrm{NaT}}$ (data not shown), as it is in neurons (Brown et al., 1994; Mantegazza et al., 1998; Taddese and Bean, 2002). In addition, $I_{\mathrm{NaP}}$ in both neurons and tsA cells has positively shifted voltage dependence of inactivation relative to $I_{\mathrm{NaT}}$. Our results with transfection of single sodium channel isoforms demonstrate that $I_{\mathrm{NaP}}$ can result from modulation of the same sodium channels that produce $I_{\mathrm{NaT}}$ (Ma et al., 1997). Thus, our working hypothesis is that $\mathrm{G} \beta \gamma$ modulation is an important regulatory influence on $I_{\mathrm{NaP}}$ in neurons.

The persistent current in a neuron is probably produced by a mixture of sodium channel subtypes with individual propensities for producing $I_{\mathrm{NaP}}$. The sodium channel $\alpha$ subunit(s) responsible for $I_{\mathrm{NaP}}$ has not been identified unequivocally in any central neuron, but it has been proposed that $\mathrm{Na}_{\mathrm{v}} 1.6$ is the primary contributor to $I_{\mathrm{NaP}}$ in cerebellar Purkinje neurons and in prefrontal cor- tex pyramidal neurons (Raman et al., 1997; Maurice et al., 2001). In addition to $\mathrm{Na}_{\mathrm{v}} 1.6$, the other primary brain $\mathrm{Na}^{+}$channel $\alpha$ subunit isoforms, $\mathrm{Na}_{\mathrm{v}} 1.1, \mathrm{Na}_{\mathrm{v}} 1.2$, and $\mathrm{Na}_{\mathrm{v}} 1.3$, all can produce $I_{\mathrm{NaP}}$. Their relative contributions could be modulated according to cell expression pattern and/or degree of neuromodulation of individual channel subtypes.

\section{Modulation of persistent sodium current in neurons}

Dynamic modulation of $I_{\mathrm{NaP}}$ would dramatically modify integrative properties of neurons. Activation of muscarinic acetylcholine receptors in hippocampal neurons reduces both $I_{\mathrm{NaP}}$ and $I_{\mathrm{NaT}}$ to comparable extents via protein kinase $\mathrm{C}$ signaling (Cantrell et al., 1996). There have been few reports of positive modulation of $I_{\mathrm{NaP}}$ in neurons (see Introduction). Increase of $I_{\mathrm{NaP}}$ by dopamine has been observed in prefrontal cortex (Gorelova and Yang, 2000) (but see Maurice et al., 2001). Modulation by free G $\beta \gamma$ in neurons might occur locally in membrane microdomains (Galbiati et al., 2001) strategically positioned to affect action potential generation in the axon hillock, action potential back-propagation at dendritic branches, or other localized electrical events. Such tightly delimited modulation might be critically important for integrative properties of the neuron but would make little contribution to whole-cell sodium current. Additional studies of sodium channel modulation by G-proteins in vitro may provide methods to probe the mechanism and significance of this form of modulation in intact neurons more incisively.

\section{References}

Alonso A, Llinas RR (1989) Subthreshold $\mathrm{Na}^{+}$-dependent theta-like rhythmicity in stellate cells of entorhinal cortex layer II. Nature 342:175-177.

Alzheimer C, Schwindt PC, Crill WE (1993) Modal gating of $\mathrm{Na}^{+}$channels as a mechanism of persistent $\mathrm{Na}^{+}$current in pyramidal neurons from rat and cat sensorimotor cortex. J Neurosci 13:660-673.

Azouz R, Alroy G, Yaari Y (1997) Modulation of endogenous firing patterns by osmolarity in rat hippocampal neurones. J Physiol (Lond) 502:175-187.

Brown AM, Schwindt PC, Crill WE (1994) Different voltage dependence of transient and persistent $\mathrm{Na}^{+}$currents is compatible with modal-gating hypothesis for sodium channels. J Neurophysiol 71:2562-2565.

Brumberg JC, Nowak LG, McCormick DA (2000) Ionic mechanisms underlying repetitive high-frequency burst firing in supragranular cortical neurons. J Neurosci 20:4829-4843.

Burbidge SA, Dale TJ, Powell AJ, Whitaker WR, Xie XM, Romanos MA, Clare JJ (2002) Molecular cloning, distribution and functional analysis of the $\mathrm{Na}_{\mathrm{v}}$ 1.6. Voltage-gated sodium channel from human brain. Brain Res Mol Brain Res 103:80-90.

Cantrell AR, Ma JY, Scheuer T, Catterall WA (1996) Muscarinic modulation of sodium current by activation of protein kinase $\mathrm{C}$ in rat hippocampal neurons. Neuron 16:1019-1026.

Catterall WA (2000) From ionic currents to molecular mechanisms: the structure and function of voltage-gated sodium channels. Neuron 26:13-25.

Chen J, DeVivo M, Dingus J, Harry A, Li J, Sui J, Carty DJ, Blank JL, Exton JH, Stoffel RH, Inglese J, Lefkowitz RJ, Logothetis DE, Hildebrandt JD, Iyengar R (1995) A region of adenylyl cyclase 2 critical for regulation by $G$ protein $\beta \gamma$ subunits. Science 268:1166-1169.

Clare JJ, Tate SN, Nobbs M, Romanos MA (2000) Voltage-gated sodium channels as therapeutic targets. Drug Discov Today 5:506-520.

Cormier JW, Rivolta I, Tateyama M, Yang A-S, Kass RS (2002) Secondary structure of the human cardiac $\mathrm{Na}^{+}$channel carboxy terminus: evidence for a role of helical structures in modulation of channel inactivation. J Biol Chem 277:9233-9241.

Crill WE (1996) Persistent sodium current in mammalian central neurons. Annu Rev Physiol 58:349-362.

Deschenes I, Trottier E, Chahine M (2001) Implication of the C-terminal region of the $\alpha$-subunit of voltage-gated sodium channels in fast inactivation. J Membr Biol 183:103-114.

Deschenes I, Neyroud N, DiSilvestre D, Marban E, Yue DT, Tomaselli GF 
(2002) Isoform-specific modulation of voltage-gated $\mathrm{Na}^{+}$channels by calmodulin. Circ Res 90:E49-E57.

Galbiati F, Razani B, Lisanti MP (2001) Emerging themes in lipid rafts and caveolae. Cell 106:403-411.

Gee SH, Madhavan R, Levinson SR, Caldwell JH, Sealock R, Froehner SC (1998) Interaction of muscle and brain sodium channels with multiple members of the syntrophin family of dystrophin-associated proteins. J Neurosci 18:128-137.

Goldin AL, Barchi RL, Caldwell JH, Hofmann F, Howe JR, Hunter JC, Kallen RG, Mandel G, Meisler MH, Netter YB, Noda M, Tamkun MM, Waxman SG, Wood JN, Catterall WA (2000) Nomenclature of voltage-gated sodium channels. Neuron 28:365-368.

Gorelova NA, Yang CR (2000) Dopamine D1/D5 receptor activation modulates a persistent sodium current in rat prefrontal cortical neurons in vitro. J Neurophysiol 84:75-87.

Hammarstrom AK, Gage PW (1998) Inhibition of oxidative metabolism increases persistent sodium current in rat CA1 hippocampal neurons. J Physiol (Lond) 510:735-741.

Hammarstrom AK, Gage PW (1999) Nitric oxide increases persistent sodium current in rat hippocampal neurons. J Physiol (Lond) 520:451-461.

Hammarstrom AK, Gage PW (2000) Oxygen-sensing persistent sodium channels in rat hippocampus. J Physiol (Lond) 529:107-118.

Herlitze S, Garcia DE, Mackie K, Hille B, Scheuer T, Catterall WA (1996) Modulation of $\mathrm{Ca}^{2+}$ channels by G-protein $\beta \gamma$ subunits. Nature 380:258-262.

Herlitze S, Hockerman GH, Scheuer T, Catterall WA (1997) Molecular determinants of inactivation and $\mathrm{G}$ protein modulation in the intracellular loop connecting domains I and II of the calcium channel $\alpha_{1 \mathrm{~A}}$ subunit. Proc Natl Acad Sci USA 94:1512-1516.

Herzog RI, Liu C, Waxman SG, Cummins TR (2003) Calmodulin binds to the $\mathrm{C}$ terminus of sodium channels Nav1.4 and Nav1.6 and differentially modulates their functional properties. J Neurosci 23:8261-8270.

Hodgkin AL, Huxley AF (1952) A quantitative description of membrane current and its application to conduction and excitation in nerve. J Physiol (Lond) 117:500-544.

Kearney JA, Plummer NW, Smith MR, Kapur J, Cummins TR, Waxman SG, Goldin AL, Meisler MH (2001) A gain-of-function mutation in the sodium channel gene $S c n 2 a$ results in seizures and behavioral abnormalities. Neuroscience 102:307-317.

Kim J, Ghosh S, Liu H, Tateyama M, Kass RS, Pitt GS (2004) Calmodulin mediates $\mathrm{Ca}^{2+}$ sensitivity of sodium channels. J Biol Chem 279:45004-45012.

Lenkowski PW, Stevens EB, Yusaf SP, Patel MK (2004) G-protein $\beta_{1} \gamma_{2}$ subunits directly bind to the C-terminus of Nav1.3 and modulate channel properties. Biophys J 87a:881.

Linford NJ, Cantrell AR, Qu Y, Scheuer T, Catterall WA (1998) Interaction of batrachatoxin with the local anesthetic receptor site in transmembrane segment IVS6 of the voltage-gated sodium channel. Proc Natl Acad Sci USA 95:13947-13952.

Ma JY, Catterall WA, Scheuer T (1997) Persistent sodium currents through brain sodium channels induced by $\mathrm{G}$ protein $\beta \gamma$ subunits. Neuron 19:443-452.

Mantegazza M, Franceschetti S, Avanzini G (1998) Anemone toxin (ATX II)-induced increase in persistent sodium current: effects on the firing properties of rat neocortical pyramidal neurones. J Physiol (Lond) 507:105-116.

Mantegazza M, Yu FH, Catterall WA, Scheuer T (2001) Role of the C-terminal domain in inactivation of brain and cardiac sodium channels. Proc Natl Acad Sci USA 98:15348-15353.

Margolskee RF, McHendry-Rinde B, Horn R (1993) Panning transfected cells for electrophysiological studies. Biotechniques 15:906-911.

Marin P, Fagni L, Torrens Y, Alcaraz G, Couraud F, Bockaert J, Glowinski J, Premont J (2001) AMPA receptor activation induces association of G-beta protein with the alpha subunit of the sodium channel in neurons. Eur J Neurosci 14:1953-1960.
Maurice N, Tkatch T, Meisler M, Sprunger LK, Surmeier DJ (2001) $\mathrm{D}_{1} / \mathrm{D}_{5}$ dopamine receptor activation differentially modulates rapidly inactivating and persistent sodium currents in prefrontal cortex pyramidal neurons. J Neurosci 21:2268-2277.

Motoike HK, Liu H, Glaaser IW, Yang AS, Tateyama M, Kass RS (2004) The $\mathrm{Na}^{+}$channel inactivation gate is a molecular complex: a novel role of the COOH-terminal domain. J Gen Physiol 123:155-165.

Pape HC, Pare D, Driesang RB (1998) Two types of intrinsic oscillations in neurons of the lateral and basolateral nuclei of the amygdala. J Neurophysiol 79:205-216.

Parri HR, Crunelli V (1998) Sodium current in rat and cat thalamocortical neurons: role of a non-inactivating component in tonic and burst firing. J Neurosci 18:854-867.

Pennartz CM, Bierlaagh MA, Geurtsen AM (1997) Cellular mechanisms underlying spontaneous firing in rat suprachiasmatic nucleus: involvement of a slowly inactivating component of sodium current. J Neurophysiol 78:1811-1825.

Qu Y, Rogers J, Tanada T, Scheuer T, Catterall WA (1994) Modulation of cardiac $\mathrm{Na}^{+}$channels expressed in a mammalian cell line and in ventricular myocytes by protein kinase C. Proc Natl Acad Sci USA 91:3289-3293.

Raman IM, Sprunger LK, Meisler MH, Bean BP (1997) Altered subthreshold sodium currents and disrupted firing patterns in Purkinje neurons of Scn8a mutant mice. Neuron 19:881-891.

Rees S, Coote J, Stables J, Goodson S, Harris S, Lee MG (1996) Bicistronic vector for the creation of stable mammalian cell lines that predisposes all antibiotic-resistant cells to express recombinant protein. Biotechniques 20:102-112.

Schwindt PC, Crill WE (1995) Amplification of synaptic current by persistent sodium conductance in apical dendrite of neocortical neurons. J Neurophysiol 74:2220-2224.

Segal MM, Douglas AF (1997) Late sodium channel openings underlying epileptiform activity are preferentially diminished by the anticonvulsant phenytoin. J Neurophysiol 77:3021-3034.

Smith RD, Goldin AL (1998) Functional analysis of the rat I sodium channel in Xenopus oocytes. J Neurosci 18:811-820.

Stuart G (1999) Voltage-activated sodium channels amplify inhibition in neocortical pyramidal neurons. Nat Neurosci 2:144-150.

Stuart G, Sakmann B (1995) Amplification of EPSPs by axosomatic sodium channels in neocortical pyramidal neurons. Neuron 15:1065-1076.

Taddese A, Bean BP (2002) Subthreshold sodium current from rapidly inactivating sodium channels drives spontaneous firing of tuberomammillary neurons. Neuron 33:587-600.

Tan HL, Kupershmidt S, Zhang R, Stepanovic S, Roden DM, Wilde AA, Anderson ME, Balser JR (2002) A calcium sensor in the sodium channel modulates cardiac excitability. Nature 415:442-447.

Thompson JD, Higgins DG, Gibson TJ (1994) Clustal W: improving the sensitivity of progressive multiple sequence alignment through sequence weighting, position-specific gap penalties and weight matrix choice. Nucleic Acids Res 22:4623-4680.

Trimmer JS, Cooperman SS, Tomiko SA, Zhou JY, Crean SM, Boyle MB, Kallen RG, Sheng ZH, Barchi RL, Sigworth FJ (1989) Primary structure and functional expression of a mammalian skeletal muscle sodium channel. Neuron 3:33-49.

Trouet D, Nilius B, Voets T, Droogmans G, Eggermont J (1997) Use of a bicistronic GFP-expression vector to characterise ion channels after transfection in mammalian cells. Pflügers Arch 434:632-638.

van Bemmelen MX, Rougier JS, Gavillet B, Apotheloz F, Daidie D, Tateyama M, Rivolta I, Thomas MA, Kass RS, Staub O, Abriel H (2004) Cardiac voltage-gated sodium channel Nav1.5 is regulated by Nedd4-2 mediated ubiquitination. Circ Res 95:284-291.

Zamponi GW, Bourinet E, Nelson D, Nargeot J, Snutch TP (1997) Crosstalk between $\mathrm{G}$ proteins and protein kinase $\mathrm{C}$ mediated by the calcium channel $\alpha_{1}$ subunit. Nature 385:442-446. 